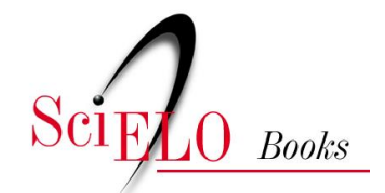

\title{
Soberania e ingerência na Amazônia brasileira
}

\author{
Petrônio De Tilio Neto
}

TILIO NETO, PD. Soberania e ingerência na Amazônia brasileira [online]. Rio de Janeiro: Centro Edelstein de Pesquisa Social, 2010, 82p. ISBN 978-85-7982-047-2. Available from SciELO Books $<$ http://books.scielo.org $>$.

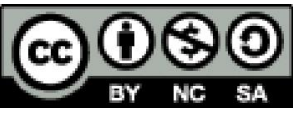

All the contents of this chapter, except where otherwise noted, is licensed under a Creative Commons Attribution-Non Commercial-ShareAlike 3.0 Unported.

Todo o conteúdo deste capítulo, exceto quando houver ressalva, é publicado sob a licença Creative Commons Atribuição Uso Não Comercial - Partilha nos Mesmos Termos 3.0 Não adaptada.

Todo el contenido de este capítulo, excepto donde se indique lo contrario, está bajo licencia de la licencia Creative Commons Reconocimento-NoComercial-CompartirIgual 3.0 Unported. 


\section{BIBLIOTECA VIRTUAL DE CIÊNCIAS HUMANAS}

\section{SOBERANIA E INGERÊNCIA}

NA AMAZÔNIA BRASILEIRA

\section{Petrônio De Tilio Neto}




\section{Petrônio De Tilio Neto}

\section{Soberania e ingerência na Amazônia brasileira}

Esta publicação é parte da Biblioteca Virtual de Ciências Humanas do Centro Edelstein de Pesquisas Sociais - www.bvce.org

Copyright (c) 2010, Petrônio De Tilio Neto

Copyright (c) 2010 desta edição on-line: Centro Edelstein de Pesquisas Sociais

Ano da última edição: 2009, Plêiade

Nenhuma parte desta publicação pode ser reproduzida ou transmitida por qualquer meio de comunicação para uso comercial sem a permissão escrita dos proprietários dos direitos autorais. A publicação ou partes dela podem ser reproduzidas para propósito não comercial na medida em que a origem da publicação, assim como seus autores, seja reconhecida.

ISBN 978-85-7982-047-2

Centro Edelstein de Pesquisas Sociais

www.centroedelstein.org.br

Rua Visconde de Pirajá, 330/1205

Ipanema - Rio de Janeiro - RJ

CEP: 22410-000. Brasil

Contato: bvce@centroedelstein.org.br

Rio de Janeiro

2010 


\section{Nota do autor}

Este livro é resultado de minha dissertação de mestrado, apresentada em 2003 ao Programa de Pós-Graduação em Ciência Política da Universidade de São Paulo (USP). Trata-se portanto de um trabalho datado, que representa um momento específico do meu percurso acadêmico. Mais do que isso, este livro apresenta o estado da arte e a configuração política vigentes naquele momento. Desde então houve diversos avanços, teóricos e práticos, sobre as questões aqui abordadas - soberania, intervenção, ingerência, integração amazônica, políticas para a região, etc.

Agradeço profundamente a todos que ajudaram na execução deste estudo. Dentre tantas pessoas nomeio apenas o professor Wanderley Messias da Costa, que me ajudou a compreender melhor a Amazônia, e o professor Leonel Itaussu Almeida Mello, meu eterno orientador. Agradeço também ao Departamento de Ciência Política e à Faculdade de Filosofia, Letras e Ciências Humanas da USP, que tão bem me acolheram. E agradeço finalmente à CAPES, que financiou meus estudos de mestrado. 


\section{SUMÁRIO}

Introdução .II

Com efeito, todos esses objetivos que não é possível atingir a não ser através da atividade política - onde necessariamente se faz apelo a meios violentos e se acolhem os caminhos da ética e da responsabilidade - colocam em perigo a "salvação da alma".

Max Weber

Os homens, de tão boa índole quanto as ovelhas que apascentam, mal proporcionam à sua existência um valor mais alto do que $o$ dos seus animais. Agradeçamos, pois, a natureza pela intratabilidade, pela vaidade que produz a inveja competitiva, pelo sempre insatisfeito desejo de ter e também de dominar! Sem eles todas as excelentes disposições naturais da humanidade permaneceriam sem desenvolvimento num sono eterno.

Immanuel Kant
Capítulo 1 - O Conceito de Soberania ... 1

Duas concepções clássicas de soberania: direito e coerção ............................. 5

Direito e coerção nas interpretações modernas de soberania ........................ 12

Mudança ou Continuidade? Concepções de soberania no pós-Guerra Fria ... 19

Capítulo 2 - Da Intervenção Ambiental à Ingerência Ecopolítica ...... 26

Debate ecológico e ecopolítica..................................................................... 27

Intervenção ambiental........................................................................... 32

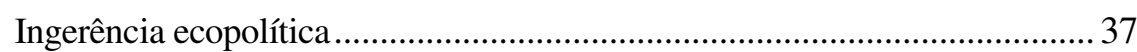

Avaliação crítica da ingerência ecopolítica ................................................. 41

Capítulo 3 - A Amazônia Brasileira................................................... 46

Mapeamento da Amazônia ....................................................................... 46

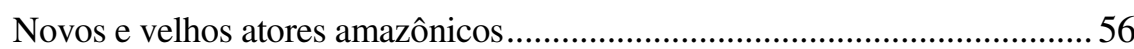

Considerações Finais 68

Bibliografia Citada 76

Bibliografia Consultada 80 


\section{INTRODUÇÃO}

Por Amazônia compreende-se aqui o vasto domínio natural que acompanha os leitos do rio Amazonas e de seus afluentes. Trata-se de um ecossistema complexo, com mais de 7 milhões de $\mathrm{km}^{2}$, que se estende por oito países e compreende cerca de $40 \%$ do espaço total da América do Sul. Constitui uma imensa reserva natural de biodiversidade, de energia hidrelétrica, de água doce, de minérios e de madeira, e encontra-se praticamente inexplorada sob alguns desses aspectos.

A integração continental da América do Sul passa, necessariamente, pela conquista e desbravamento da Amazônia. É a bacia hidrográfica do Amazonas que liga a cordilheira andina ao Atlântico caribenho; torna possível o acesso do promontório nordestino brasileiro ao interior do continente; ao sul, interligando-se artificialmente aos rios da Bacia Platina, permite que o extremo meridional do continente se integre às demais regiões. Trata-se, portanto, de uma importante região de integração continental.

Essas características fazem da Amazônia um tema de especial interesse para a Ciência Política. Entretanto, o que se tem verificado no Brasil é uma escassez de trabalhos em Ciência Política que atentem para a região amazônica. É bem verdade que muitos avanços científicos têm sido feitos nas últimas décadas, e que a cada ano surgem novos e surpreendentes desenvolvimentos. No caso específico do meio ambiente é possível notar as capacidades de mensuração e de coleta de dados cada vez mais aprimoradas, vasculhando com uma minúcia espetacular cada centímetro quadrado do espaço terrestre. Quanto a isso, não se pode reclamar. O que tem faltado, de fato, são interpretações qualitativas para essa imensa quantidade de dados colhidos a cada momento. Falta pensar todo esse material bruto. A cada passo que se dá no campo da técnica, fica faltando o avanço correspondente no campo da filosofia. Este trabalho não pretende sozinho, evidentemente, sanar essa lacuna. Mas, fazendo sua parte, pretende contribuir para que pesquisas de nível cada vez mais alto sejam desenvolvidas, na área das humanidades, com preocupações ambientais.

O que se procura fazer aqui é tratar de temas aparentemente tão díspares quanto a questão ambiental e a soberania estatal. A primeira é um tema consagrado nos últimos anos pela mídia e pela ciência, especialmente após o final da bipolarização militar e ideológica vigente durante a Guerra Fria, que a tudo abrangia e pouco espaço deixava para o advento de temas novos ${ }^{1}$. Já a soberania é um conceito clássico e tradicional, um dos motes centrais da Ciência Política desde a formalização desta no século XVI por Nicolau Maquiavel, e tem especial importância no contexto dos Estados modernos - territoriais, nacionais e soberanos.

Pretende-se ligar esses dois temas por meio de um artifício bem definido. Trata-se no fundo de um estudo de caso da porção brasileira da Amazônia, e da posição que o Brasil manteve/mantém com respeito à sua soberania nacional dentro desse espaço. As formas nacionais de ocupação desse espaço muitas vezes se dão de modo caótico e desordenado, com imensos danos ao meio ambiente. No contexto atual, onde o meio ambiente se torna objeto de preocupação internacional, não se descarta a eventualidade de tentativas de interferência externa, por parte de um ou mais países, na Amazônia brasileira. Ameaças de apropriação estrangeira, que são uma forma mais radical dessas tentativas de interferência externa, datam praticamente do descobrimento do continente, com as incursões francesas, holandesas e inglesas no território luso-brasileiro, além dos constantes conflitos com o reino de Espanha. Ao mesmo tempo a invasão estrangeira na Amazônia é um tema recente: o meio ambiente é um dos temas que veio à tona com força especial após o fim da Guerra Fria, e a Amazônia é uma região riquíssima tanto em termos ecológicos quanto em reservas minerais, bem como uma imensa fonte de energia hidrelétrica e de água doce. Trata-se, ainda assim, de um território nacional, isto é, apesar de possíveis dúvidas quanto à demarcação exata das fronteiras, cada árvore ou cada pequeno pedaço de solo amazônico se encontra indubitavelmente em espaço nacional específico de um determinado país - seja do Brasil, da Venezuela, da Guiana ou de qualquer outro país amazônico.

A Amazônia também é um dos últimos grandes espaços ainda não ocupados pelo homem, e dentre esses talvez o menos difícil de se ocupar as outras opções mais notáveis são os círculos polares, os oceanos propriamente ditos, e as regiões desérticas. Trata-se, portanto, de uma fronteira de recursos de nível mundial, e não apenas nacional - e, diga-se de

${ }^{1}$ Sobre novos temas e novos atores na cena internacional, v. VILLA, Rafael A. D, 1999: $D a$ Crise do Realismo à Segurança Global Multidimensional, Annablume, São Paulo. 
passagem, os recursos oferecidos por essa fronteira não são nada desinteressantes. A ocupação da Amazônia constitui um legítimo desafio, e como tal necessita de uma resposta criadora.

Cumpre expor a seguir, de modo resumido, a estrutura que este trabalho procurou seguir.

No primeiro capítulo a preocupação central será a soberania propriamente dita: suas características, suas implicações, e as mudanças pelas quais ela pode estar passando no tempo presente. A análise centrará seu foco basicamente sobre duas correntes de pensamento, como será explicitado mais adiante. Uma corrente remonta ao jurista francês do século XVI, Jean Bodin, para quem a soberania deriva da esfera do direito. A outra corrente remete ao pensador inglês do século XVII, Thomas Hobbes, segundo o qual a soberania pertence à esfera do poder político enquanto força propriamente dita, de forma concordante com a tradição inaugurada por Maquiavel.

No segundo capítulo será tratada a faceta oposta à soberania: a questão da intervenção internacional, e como ela se liga às novas e prementes preocupações ambientais. O fim da bipolarização que por meio século dividiu o plano das ideias entre o liberalismo e o comunismo abriu espaço para o surgimento de novos temas nas relações internacionais, como a questão ambiental, as preocupações humanitárias e a segurança global. Esses novos temas passam a ser discutidos nos fóruns internacionais que se reavivam, e é daí que surge a preocupação dos Estados com relação a intervenções ecológicas supranacionais. A Amazônia, é claro, não é o único exemplo. Florestas tropicais também são alvo de preocupações semelhantes na África, no sudeste asiático e na Oceania.

O terceiro capítulo se destina a um mapeamento da região amazônica brasileira, bem como das políticas nacionais de ocupação desse espaço. Por meio dessas políticas, cercadas pelo discurso ambiental, pretende-se desvelar o posicionamento brasileiro com relação à soberania na região. Por "posicionamento brasileiro", como será melhor explorado mais adiante, entende-se aqui uma postura tipicamente nacional, consciente das prerrogativas e peculiaridades da Amazônia brasileira e que assuma uma postura identificável com relação a essas prerrogativas e peculiaridades. Deve possuir uma certa consistência interna, e uma coerência com relação a fins, meios ou valores. Pode-se adiantar que, com o final da Guerra Fria e com o processo de redemocratização brasileiro, surge espaço para uma mudança nos temas fundamentais em pauta - da soberania ao meio ambiente -, e também nos atores formuladores de políticas - de atores estatais como militares e diplomatas a atores da sociedade civil e econômicos, como ONG's, intelectualidade acadêmica e empresas multinacionais.

Não é necessário dizer, este trabalho não pretende esgotar os temas dos quais se ocupa, mas sim estudá-los e oferecer alguma contribuição ao entendimento que atualmente se tem dessas questões. É o objetivo deste trabalho levantar e introduzir alguns problemas de interesse científico e humanístico com relação aos temas, refletir um pouco, e talvez propor caminhos para a elucidação de alguns problemas que possam surgir durante esse percurso. Trata-se, em todo caso, de uma análise preliminar, a ser aprofundada no devido tempo e com a exigida competência. 


\section{CAPÍtULO 1}

\section{O CONCEITO DE SOBERANIA}

Este trabalho pretende tratar de um problema bem específico: descobrir se o Brasil está munido, no que diz respeito à soberania nacional, de um posicionamento estruturado com relação à floresta amazônica. Por "posicionamento estruturado" entende-se uma certa coerência das atitudes adotadas, seja com relação aos fins almejados, aos valores defendidos, ou aos meios empregados. A significação mais precisa de um posicionamento tal, suas implicações, e como se pretende apreender um eventual posicionamento brasileiro são pontos que serão deixados mais para adiante, a serem melhor explorados no desenrolar deste trabalho. $\mathrm{O}$ presente capítulo destina-se a abordar o tema que inspira e direciona o trabalho: seu mote central, a soberania.

Cabe iniciar, portanto, definindo soberania, ainda que de forma provisória. Nicola Matteucci, no Dicionário de Política, diz que

Em sentido lato, o conceito político-jurídico de Soberania indica o poder de mando de última instância, (...) [e que esse conceito] pretende ser a racionalização jurídica do poder, no sentido da transformação da força em poder legítimo, do poder de fato em poder de direito ${ }^{2}$

Tal afirmação, da forma como foi construída, leva a pensar a soberania segundo dois referenciais, indissociáveis porém distintos: primeiro, sua caracterização como mando de última instância; segundo, se suas atribuições se devem ao poder, ao direito, ou a ambos ao mesmo tempo.

Quanto ao primeiro referencial, Matteucci aponta que o termo soberania aparece, em sentido restrito (ou seja, como instrumento teórico, e portanto com significação precisa), no final do século $\mathrm{XVI}^{3}$. Os termos soberania e Estado teriam surgido juntos, o primeiro para qualificar o

\footnotetext{
${ }^{2}$ MATTEUCCI, 1986, p. 1179
}

${ }^{3}$ MATTEUCCI, 1986, p. 1179. último como sujeito único e exclusivo das relações de poder. A concepção de Estado adotada por este trabalho será a weberiana, segundo a qual

(...) devemos conceber o Estado contemporâneo como uma comunidade humana que, dentro dos limites de determinado território (...) reivindica o monopólio do uso legítimo da violência física ${ }^{4}$.

Como Norberto Bobbio, este trabalho assume que a concepção weberiana de Estado propõe uma certa descontinuidade entre as formas de organização política mais antigas e as tipicamente modernas 5 .

A formação do Estado moderno teria se dado, segundo Weber, a partir de um duplo processo de expropriação: de um lado, a expropriação capitalista dos meios de produção manufatureiros; de outro, a expropriação dos meios de coerção por parte do Estado ${ }^{6}$. A expropriação dos meios de produção das mãos dos grandes proprietários de terra teria possibilitado a um Estado embrionário tornar-se o proprietário dos meios de gestão de que necessitava, garantindo-lhe um domínio completo e exclusivo sobre seu aparato governamental. Ao mesmo tempo a expropriação dos meios de coerção por parte do governante lhe garantiria o monopólio do uso legítimo da força física em seu território. Com uma certa ironia, o processo de racionalização e centralização acabaria em seguida expropriando o próprio expropriador, tirando das mãos do governante singular a posse dos meios de gestão e o monopólio da violência, e depositando-os na própria figura abstrata do ordenamento político - inicialmente a Coroa e, num momento posterior, o Estado ${ }^{7}$.

\footnotetext{
${ }^{4}$ WEBER, 1999, p 56; grifos do autor.

${ }^{5}$ BOBBIO, 1995, pp. 67-70.

${ }^{6}$ WEBER, 1999, p. 62

${ }^{7}$ De acordo com Weber a força sozinha - ou mesmo o monopólio de toda a força disponível - não é suficiente para garantir a obediência dos súditos (WEBER, 1999, pp. 57-8). É necessário, sobretudo, que o povo consinta na utilização dessa força. Tal consentimento se restringe às situações em que o povo considera justa e necessária a aplicação da força - ou seja, quando a aplicação da força é considerada legítima. Apenas nesses casos seu uso é tolerado, e o sistema político pode esperar alguma estabilidade e duração. Assim, mais do que o monopólio da força, o Estado precisa de (e de fato conta com) o monopólio da força legítima. Weber identifica três razões internas que legitimam a dominação - ou, três tipos puros de dominação legítima: o carismático, o tradicional e o racional-legal (WEBER, 1999, pp. 57-8; v. também WEBER, Max, 1986: "Os três tipos puros de dominação legítima", in
} 
A formação do Estado moderno seria, assim, o ponto alto de um processo de centralização que se opunha, por um lado, às categorias ou ordens da organização medieval, particularistas e atomísticas, e, por outro lado, às pretensões universalistas do Papado e do Império. Essa dupla oposição evidencia a dupla face, interna e externa, da soberania estatal. Pode-se considerar que internamente, na relação entre governante e governado ou entre Estado e súdito, a soberania visa a despolitização e a neutralização da sociedade, substituindo todos os conflitos por processos administrativos. Também externamente, nas relações entre Estados, as relações políticas seriam substituídas por artifícios cada vez mais neutros e despolitizados: tratados disciplinados e racionalizados, e o direito internacional ou direito público europeu. Assim considera-se que o Estado soberano detém internamente uma supremacia absoluta - tendo abaixo de si apenas os súditos, obrigados a obedecer - e externamente se encontra em posição de igualdade com relação aos demais soberanos - não reconhecendo nenhuma instância superior à qual deva obediência.

A soberania aparece, portanto, como a culminação de um processo de expropriação das funções propriamente políticas, internas e externas, por parte do Estado moderno. Essa será a concepção de soberania adotada neste trabalho. Essa concepção será aqui enfocada com relação a seu aspecto externo. Desse modo, é apenas de forma colateral que este trabalho se preocupa com a manutenção da ordem interna por um poder legítimo e absoluto dentro de um território. Preocupa-se, mais especificamente, com as relações entre as unidades políticas soberanas, os Estados modernos, apegando- se assim ao ponto de vista das Relações Internacionais. E ainda, este trabalho se ocupará apenas de forma colateral com o que se possa considerar ameaças internas à soberania brasileira na Amazônia (como traficantes, reservas indígenas, extração ilegal de recursos, guerrilhas, etc.). Sua preocupação se dirige sobre o que for entendido como tentativa ou possibilidade de intervenção internacional na Amazônia brasileira, por parte de um ou mais Estados soberanos, sejam a fonte dessa intervenção organizações governamentais como a ONU e a OTAN, organizações não governamentais, ou ainda particulares estrangeiros.

Max Weber - Sociologia, Editora Ática, São Paulo). Essa última se refere principalmente ao Estado moderno, onde a validade do estatuto legal é o critério de legitimação.
Quanto ao segundo eixo referencial, a dicotomia poder de fato-poder de direito, Matteucci aponta que a soberania se pretende um conceito político-jurídico, isto é, assume ao mesmo tempo as formas de força e de direito. Isso é coerente com a concepção weberiana, pois dizer, como Weber, que o Estado moderno monopoliza a violência legítima equivale a dizer que ele possui uma capacidade de coerção que é aceita com base em sua legitimidade ${ }^{8}$, ou seja, que conta com um direito 9 .

Sendo ambos, coerção e direito, aspectos fundamentais da soberania, parece importante procurar entender melhor a relação existente entre eles. De um lado é possível pensar na "força da lei", uma ideia segundo a qual a soberania consistiria no mando justo, no qual deveria se pautar toda ação estatal, e ao qual deveria estar submetido todo o uso que o Estado faz da coerção. No polo oposto estaria situada a ideia da "lei da força", segundo a qual o direito deriva da capacidade efetiva de mando, ou seja, as leis são impostas pelo mais forte. De acordo com Matteucci

A unilateralidade destas duas posições, se levada ao extremo, poderia conduzir ou a um direito sem poder ou a um poder sem direito, quebrando assim aquele delicado equilíbrio entre força e direito que continua sendo, em qualquer situação, o objetivo último dos teóricos da Soberania ${ }^{10}$.

Essa é uma discussão que ainda permanece em aberto entre os teóricos, e não é o objetivo desta dissertação tentar resolvê-la. No entanto, segundo a concepção de soberania aqui adotada, parece indiscutível que o Estado pretenda para si um poder soberano e absoluto, tanto de fato quanto de direito.

Cabe tentar deixar claras essas duas posições, e procurar entender como se dá e se mantém o equilíbrio entre ambas. Cada posição será melhor analisada a seguir, enquanto será discutido o conceito de soberania em dois autores que podem ser considerados os principais sustentáculos da teoria da soberania: Jean Bodin (1530-1596) e Thomas Hobbes (1588-1679). Para o primeiro a essência da soberania reside no poder de fazer e de anular as leis.

\footnotetext{
${ }^{8}$ V. nota 7.

${ }^{9}$ Para uma reconstrução histórica e analítica do surgimento da soberania do século $\mathrm{X}$ ao XIV, em sua associação entre força e direito, v. KRITSCH, Raquel, 2002: Soberania: a construção de um conceito, Humanitas/Imprensa Oficial do Estado, São Paulo.
}

${ }^{10}$ MATTEUCCI, 1986, p. 1180 
Já para o segundo a soberania pode ser encarada, com maior propriedade, como o poder coativo de se fazer obedecer.

\section{DUAS CONCEPÇÕES CLÁSSICAS DE SOBERANIA: DIREITO E COERÇÃO}

O objetivo de Jean Bodin é, através do direito, criar um sistema de ordenamento do mundo que permita compreender e organizar a vida do homem em sociedade. Nesse sentido o direito não é, para esse autor, um dado puramente empírico. É, mais do que isso, uma tradução de um ideal universal de justiça às diferentes sociedades humanas. Ao agrupamento humano mais amplo, onde o direito se expressa e toma forma, Bodin chama república. Esse termo pode ser entendido como sinônimo de Estado. Segundo Bodin, "República é um governo justo de várias famílias, e do que lhes é comum, com poder soberano" ${ }^{11}$.

O elemento constitutivo da república é, portanto, a família, governada pelo chefe ou cabeça de família. O mesmo princípio de uma só cabeça rege o universo (cuja cabeça é Deus), e o próprio corpo humano. Portanto nada mais natural, segundo Bodin, que uma só cabeça governe o corpo social que é a república. E o fato de isso ser natural é de suma importância no pensamento bodiniano, já que o governo justo que deve reger a república é exatamente aquele que segue as leis da natureza, que são leis ao mesmo tempo racionais e divinas ${ }^{12}$.

Essa relação de mando e obediência significa uma limitação da liberdade natural de cada súdito, isto é, da liberdade de viver segundo o próprio arbítrio, dependendo apenas da razão e da vontade de Deus. Em uma relação de mando tal liberdade é posta sob o poder de outro: no caso da família, sob o cabeça de família, e no caso da república, sob o soberano, detentor da soberania. Antes da instituição da república, cada cabeça de família seria soberano em sua própria família. Com a união de diversas famílias, constituindo a república,

\footnotetext{
${ }^{11}$ BODIN, 1992, p. 9; livre-tradução.

12 BODIN, 1992, pp. 9-11. Bodin não define explicitamente essas leis da natureza, mas parece deixar claro que se trata de leis da razão, que expressam a vontade divina, e que são apreensíveis por meio da contemplação (v., por exemplo, pp. 13-4 e p. 60). As leis naturais parecem remeter principalmente à equidade, que cabe ao príncipe garantir de forma harmônica (isto é, combinando as justiças comutativa e distributiva), por meio da criação e correção da lei civil (v. p. 63 e pp. 297-306).
}

esse poder se concentraria em um dos chefes (ou em uma parte deles, ou em todos eles em conjunto), sobre cada chefe em particular.

De acordo com Bodin "A soberania é o poder absoluto e perpétuo de uma república (...)." ${ }^{\prime 3}$. A soberania seria perpétua porque o soberano pode outorgar seu poder a um ou mais súditos, por um tempo determinado, sem deixar de ser soberano. Isso significa que o soberano pode tomar de volta suas prerrogativas no momento em que quiser, tendo ou não se esgotado o mandato por ele concedido, ou ainda tolerar que esse mandato continue por mais tempo do que o previsto. Em outras palavras, o soberano delega apenas o exercício da soberania, mas não sua titularidade. Sendo assim, dizer que a soberania é perpétua equivale a dizer que ela dura enquanto durar a vida do soberano. Trata-se, portanto, de uma instituição. E pode-se dizer também, embora Bodin não o faça explicitamente, que a soberania é perpétua porque continua existindo enquanto perdurar a república - ou seja, no fundo ela continua existindo além da pessoa do soberano. Bodin também diz que a soberania é absoluta na medida em que ela não conhece condições que a limitem. O soberano não conhece limites quanto ao tempo, quanto à responsabilidade, ou quanto a seus encargos de governo. É então impossível que o soberano seja instituído por tempo limitado, ou mediante determinadas obrigações, ou com limitações sobre seus poderes. O principal atributo do soberano é o poder de dar leis a todos em geral e a cada um em particular, sem precisar contar com o consentimento de superior, igual ou inferior. Desse atributo é que derivam todas as suas demais prerrogativas ${ }^{14}$.

Essas características são verdadeiras apenas no que concerne à lei civil ou direito positivo. Isso significa que o soberano não está obrigado para com as leis de seus predecessores, e nem para com as suas próprias. Também não depende da aprovação de outras instâncias tais como conselheiros, instituições, ou súditos em geral. Desse ponto de vista o soberano é a fonte de toda a lei. Entretanto, o soberano bodiniano se encontra de fato constrangido por alguns fatores. Inicialmente, precisa reconhecer e submeter suas leis a uma ordem moral superior (às leis naturais e divinas) ${ }^{15}$. Nesse sentido o soberano não é mais a fonte de toda a lei, e sim o tradutor de uma justiça

${ }^{13}$ BODIN, 1992, p. 47; livre-tradução.

${ }^{14}$ Para as características da soberania (isto é, seu caráter perpétuo e absoluto), v. BODIN, 1992, pp. 47-66. Para seus atributos, v. BODIN, 1992, pp. 72-84.

${ }^{15}$ V. nota 12 
superior. Não são, portanto, todas as coisas que se encontram submetidas ao poder soberano. As leis naturais o obrigam, por exemplo, a respeitar a família e a propriedade privada. Em segundo lugar, o soberano se encontra obrigado pelos contratos que firme, seja com outros príncipes soberanos, seja com seus próprios súditos. Contratos não são leis; apenas com relação às últimas o poder do soberano é pleno, não havendo quem possa questioná-lo, súdito ou não (com exceção, é claro, de Deus e das leis naturais). Já no que diz respeito aos contratos o soberano se vê em pé de igualdade com as demais partes contratantes, quem quer que sejam. Dessa forma, honrar os contratos é uma necessidade frente à equidade pregada pelas leis naturais. Mais do que isso, sendo o fiador da confiança que os homens têm uns nos outros, é necessário que o soberano não dê ele próprio um mau exemplo cometendo o delito do perjúrio. Finalmente, como uma terceira limitação, o soberano deve acatar e manter inalteradas as leis constitutivas da república. As leis naturais, como o direito de sucessão e as leis de fundação do Estado, são intocáveis, por serem a base sobre a qual se apoia a majestade soberana.

Ao contrário de Bodin, que encontra na família os princípios de organização da república, Hobbes deriva seu Estado das paixões individuais dos homens. Hobbes parte do - mas não se limita ao - jusnaturalismo ${ }^{16}$, e encontra na natureza humana uma inesgotável propensão à discórdia e à guerra $^{17}$. Dada essa propensão o estado de natureza - onde todos têm direito a tudo - se apresenta como um estado de guerra generalizada de cada homem contra todos os outros. Em tal situação, onde "o homem é o lobo do homem”, a insegurança reina absoluta, a única certeza é a de que “(...) a vida do homem é solitária, pobre, sórdida, embrutecida e curta"18 e apenas uma atitude parece racional:

Que todo homem deve esforçar-se pela paz, na medida em que tenha esperança de consegui-la, e caso não consiga pode procurar e usar todas as ajudas e vantagens da guerra ${ }^{19}$.

\footnotetext{
${ }^{16} \mathrm{Na}$ verdade, há uma discussão sobre se a filosofia política hobbesiana é melhor classificada como jusnaturalista ou como positivista jurídica. Norberto Bobbio vê em Hobbes uma transição da primeira para a segunda. V. BOBBIO, Norberto, 1991: Thomas Hobbes, Campus, Rio de Janeiro.

${ }^{17}$ HOBBES, 1979, cap. XIII.

${ }^{18}$ HOBBES, 1979 , p. 76

${ }^{19}$ HOBBES, 1979 , p. 78
}

Esta é a primeira e mais importante lei natural, um preceito geral estabelecido pela razão $0^{20}$.

Desse modo a primeira lei natural - assim como as demais - é contrária às paixões dos homens. Os homens só a respeitariam quando sentissem vontade e quando pudessem fazê-lo com segurança. Assim Hobbes propõe, como decorrência da primeira lei natural, a instituição de um poder comum que garanta a segurança aos homens, e que os obrigue a buscar esse objetivo racional que é a paz coletiva.

Portanto Hobbes deriva da lei natural a transição do estado de natureza para o estado civil, por meio de um contrato do qual fariam parte todos os homens ${ }^{21}$. Segundo esse contrato cada homem transfere a uma única e mesma pessoa - seja um indivíduo ou uma assembleia - seu direito natural a todas as coisas, com a condição de que, ao fazê-lo, todos os demais façam o mesmo. Tal poder instituído visa proteger os membros dessa coletividade tanto de inimigos externos quanto de injúrias internas, garantindo-lhes segurança - e, portanto, o usufruto de seu trabalho e uma vida mais satisfeita. Com essa transferência de direitos os homens guardam para si apenas seu direito à vida que a primeira lei natural pressupõe inalienável.

A tal poder comum, instituído pelo contrato, Hobbes dá o nome de Estado, e define sua essência como sendo

Uma pessoa de cujos atos uma grande multidão, mediante pactos recíprocos uns com os outros, foi instituída por cada um como autora, de modo a ela poder usar a força e os recursos de todos, da maneira que considerar conveniente, para assegurar a paz e a defesa comum ${ }^{22}$.

E diz ainda que "Àquele que é portador dessa pessoa se chama soberano, e dele se diz que possui poder soberano" ${ }^{\prime 23}$.

Dadas as características do contrato hobbesiano pode-se considerar a soberania em Hobbes como portadora de três características

\footnotetext{
${ }^{20} \mathrm{Na}$ verdade apenas a primeira parte da sentença é uma lei natural; a segunda parte constitui, mais propriamente, um direito natural (HOBBES, 1979, p. 78).

${ }^{21}$ Para mais detalhes sobre as características dos contratos, v. HOBBES,

1979 , cap. XIV e cap. XVI

HOBBES, 1979, p. 106.

${ }^{23}$ HOBBES, 1979, p. 106; grifos do autor.
} 
fundamentais ${ }^{24}$. Em primeiro lugar ela é irrevogável, já que o que se transmite não é o mero exercício de determinados direitos, e sim sua titularidade. A soberania é fundada por um contrato que é celebrado entre indivíduos, e não entre povo e soberano. Dessa forma nem povo nem soberano podem ser acusados de descumprimento do contrato, já que foi esse ato que os transformou em povo e em soberano. Antes do contrato existiam apenas indivíduos isolados. Além disso a rescisão do contrato não depende apenas de um consenso - por si só improvável - entre todos os indivíduos contratantes. Depende também da concordância de um terceiro, não contratante, beneficiário do contrato - a pessoa do soberano.

A soberania hobbesiana também é absoluta, na medida em que marca a substituição de uma pluralidade de vontades individuais por uma única vontade, a vontade soberana. Enquanto no estado de natureza todos têm direito a tudo, no estado civil os homens abrem mão desse direito em favor do soberano, e este passa a ser o único que continua com seu direito natural sobre todas as coisas. Mais do que isso, os atos do soberano são todos autorizados de antemão pelos indivíduos que contrataram entre si. Essa centralização do direito a tudo na pessoa do soberano é o que funda o estado civil e garante a sobrevivência dos homens em coletividade.

Finalmente, a soberania é indivisível. A pessoa do soberano é única e monolítica, seja ela um homem ou uma assembleia de homens (aristocrática ou democrática). Embora o soberano possa abrir mão do exercício de alguns de seus direitos em favor de quem quer que seja, essa não é uma transferência válida e irrevogável, pois não constitui na verdade uma alienação da titularidade do direito, e sim uma concessão temporária de seu exercício, que pode ser desfeita a qualquer momento. A soberania só pode ser alienada como um todo. A não ser que o soberano abra mão expressamente da própria soberania, e que abandone o próprio título de soberano, qualquer concessão que ele faça não diminui realmente seu poder.

A visão que Bodin e Hobbes têm das relações internacionais aparece como uma extrapolação de suas construções teóricas. Basicamente, deixam de se referir às fronteiras internas de um único Estado para tratar das relações entre os diversos Estados do sistema.

\footnotetext{
${ }^{24}$ Essa ideia é apresentada em BOBBIO, Norberto, 1991, Thomas Hobbes, Campus, Rio de Janeiro, p. 43.
}

Bodin afirma que o soberano deve, internamente, manter-se neutro com relação às facções que ameaçam fracionar a república. Apoiando um ou outro lado o soberano deixa sua posição superior, de magistrado, para igualar-se a uma das facções, revestindo a si mesmo de uma vulnerabilidade que não é própria da soberania ${ }^{25}$. Do mesmo modo, nas relações interestatais, o soberano deve adotar uma posição neutra frente aos conflitos entre os demais Estados. O objetivo da neutralidade é manter um equilíbrio de poder, garantindo que nenhum lado se torne poderoso a ponto de pôr em risco a autonomia dos demais Estados do sistema. Tal neutralidade, visando o equilíbrio de poder, pode adotar uma atitude simplesmente passiva - não apoiando qualquer um dos lados, especialmente o lado mais forte - ou ativa - buscando conciliar os contendores ${ }^{26}$.

Para Hobbes o Estado soberano não reconhece externamente qualquer poder superior ao seu. Sendo essa uma posição generalizada entre todos os Estados, pode-se dizer que eles se encontram entre si em uma situação de estado de natureza e de anarquia, onde não existe um superior comum. Portanto o sistema interestatal é no fundo um estado de natureza, e como tal tende a se transformar em um estado de guerra potencial, dada a relação de insegurança mútua que impera entre os Estados.

Do ponto de vista das relações internacionais não parece haver diferenças inconciliáveis entre os sistemas bodiniano e hobbesiano. Em ambos os sistemas os Estados só têm em comum as leis naturais, mas essas costumam ser ineficazes e inócuas: para Bodin pela inexistência de magistrados - a lei encarnada ${ }^{27}$ - com jurisdição sobre os Estados, e para Hobbes pela ausência de um poder comum que garanta seu cumprimento. $\mathrm{O}$ equilíbrio de poder de Bodin não elimina a insegurança que acomete os atores hobbesianos, pois nada garante que estes, apaixonados e propensos à discórdia, o aceitem. Mas, por outro lado, equilíbrio de poder e busca de segurança não são de forma alguma incompatíveis, já que o primeiro é uma opção racional para os Estados hobbesianos, que se pautam naturalmente pela segunda. Além do mais a visão hobbesiana da totalidade, como um grande sistema de Estados sem poder comum, poderia ser lida na teoria de Bodin como uma república mundial com numerosas facções (os Estados)

\footnotetext{
${ }^{25}$ BODIN, 1992, livro quarto, capítulo VII.

${ }^{26}$ BODIN, 1992, livro quarto, capítulo VII.

${ }^{27}$ BODIN, 1992, livro três, capítulo III.
} 
em constante guerra civil, lutando entre si pelo mando sobre os demais, e sem um poder soberano unanimemente reconhecido - ainda que na prática essas facções possam se manter indefinidamente em equilíbrio.

Se sob essa ótica puramente operacional Bodin e Hobbes são compatíveis, eles são fundamentalmente diferentes em um nível teórico mais profundo. Hobbes não limita seu soberano como faz Bodin: inicialmente, o soberano hobbesiano não está obrigado para com as leis constitutivas do Estado, nem para com as leis de sucessão - em suma, para com as leis civis ou direito positivo. Em segundo lugar o soberano hobbesiano não está limitado pelos contratos que firma. No âmbito externo, não havendo nenhuma instância superior que obrigue o cumprimento dos contratos, o soberano submete estes à segurança de sua vida e à de seu Estado, e só os cumpre quando tem vontade ou quando se sente seguro para fazê-lo, como os indivíduos isolados no estado de natureza. Internamente, sendo o portador dos direitos dos súditos (com exceção do direito à vida), e tendo sido autorizado de antemão por estes em todos os seus atos, nada do que o soberano faça pode constituir injustiça contra os súditos.

Sendo a lei natural a lei de última instância para ambos os autores, em ambos os sistemas o soberano deveria submeter- se a ela. Como, então, é permitido ao soberano hobbesiano muito mais do que ao bodiniano? $\mathrm{O}$ que ocorre é que, em Bodin, as leis naturais constituem restrições concretas ao poder soberano (algo como "respeitar a propriedade", "respeitar contratos e convenções", etc.), e portanto o limitam de fato. Para Hobbes, por outro lado, a primeira lei natural é justamente a que, visando garantir a vida, impele à paz. Dessa lei Hobbes deriva a necessidade do contrato civil, e daí a soberania. Portanto as leis civis (do Estado e do soberano), para Hobbes, são um desenvolvimento direto e necessário da primeira lei natural. Assim, segundo Hobbes, se a equidade ou o direito à propriedade derivam de leis naturais secundárias, as leis civis derivam diretamente da primeira lei natural, cujo objetivo de garantir a paz e a vida se sobrepõe às recomendações das demais.

Assim, enquanto para Bodin as leis naturais constituem restrições reais às leis civis, para Hobbes elas são uma espécie de "carta branca", uma permissão absoluta e ilimitada para o exercício do poder civil (impondo-se apenas a defesa da vida dos contratantes). Em ambos os casos é ao poder civil que cabe a regulação do uso da força. Desse modo fica justificado que se entenda a soberania em Bodin como uma espécie de "império da lei", e em Hobbes como uma espécie de "império da força". Enquanto Hobbes propõe um poder que não conhece impedimentos jurídicos, Bodin propõe um poder que precisa desenvolver virtudes morais para cumprir seu papel de fiador da confiança que os homens têm uns nos outros.

\section{DIREITO E COERÇÃo NAS INTERPRETAÇÕES MODERNAS DE SOBERANIA}

Direito e coerção são agora, para os propósitos deste trabalho, dois termos que polarizam o conceito de soberania. Esses termos podem ser aqui entendidos em um sentido mais amplo que o usual, isto é, podem ser usados para se referir a direito e coerção, ou a poder de direito e poder de fato, ou ainda a jurisprudência e política. As raízes de ambos já foram devidamente fixadas em autoridades que as fundam e justificam, ou seja, respectivamente, em Bodin e em Hobbes. Alicerçado nas bases sólidas desses dois autores este trabalho pretende a seguir verificar a continuidade da dicotomia teórica entre direito e coerção, no que concerne à soberania, em autores contemporâneos que tratam do tema. Tal artifício se destina a demonstrar como é persistente essa dicotomia e, ao mesmo tempo, a tomar contato com algumas das variações que autores mais recentes encontram na problemática.

Do lado do direito é desejável começar com o autor que inspirou as concepções de paz internacional e de Liga das Nações no primeiro pósguerra. Trata-se de Hans Kelsen (1881-1973), herdeiro da teoria pura do direito kantiana. Kelsen diferencia o direito tanto da política (ou da filosofia política, campo do dever ser) quanto da sociologia (campo da conduta real dos indivíduos), e se preocupa apenas com o que chama Direito positivo, um direito real e normativo, relativo a comunidades específicas e localizadas ${ }^{28}$.

Para Kelsen o Estado se resume a um sistema de normas, e a teoria do Estado não seria nada mais do que um ramo da teoria do direito. O que confere realidade ao Estado seria justamente sua faceta de ordenamento jurídico $^{29}$. Segundo esse autor a força física se submete ao direito, o que possibilita que se tratem todos os problemas da teoria do Estado como problemas de ordem jurídica. É o caso, por exemplo, dos três elementos que Kelsen aponta como constituintes do Estado: o território, o povo e o poder. O

${ }^{28}$ KELSEN, 2000, pp. XXVII-XXIX.

${ }^{29}$ KELSEN, 2000, pp. 261-4. 
território é definido por Kelsen como a esfera espacial onde o controle jurídico estatal possui eficácia. Da mesma forma o povo de um Estado se refere à porção da humanidade onde sua ordem jurídica se aplica de modo eficaz. Quanto ao poder não haveria a princípio qualquer matéria fora da competência do Estado, a não ser que o próprio ordenamento jurídico assim decida.

Kelsen propõe uma unidade fundamental entre o direito nacional e o internacional ${ }^{30}$. Sendo a comunidade internacional, segundo Kelsen, uma comunidade específica como qualquer outra, nada impede que nela se forme um direito característico. Contra a ideia de que os Estados criam o direito internacional por meio de tratados, Kelsen propõe que a comunidade internacional é quem cria o direito internacional. Da mesma forma que a comunidade nacional - o Estado formado por indivíduos - cria o direito nacional, a comunidade internacional, tendo os Estados como elementos constitutivos, criaria um direito próprio.

Os Estados seriam, assim, uma necessidade lógica para a existência do direito internacional. Mas este último - cuja existência Kelsen assume como ponto de partida - não apenas pressupõe os primeiros, como também os determina. Segundo Kelsen, por definição, a comunidade jurídica é justamente a entidade capaz de obrigar juridicamente seus elementos constitutivos. Ou seja, a mesma jurisdição total e eficaz que o Estado possui sobre os indivíduos, a comunidade jurídica internacional possui sobre os Estados. O direito internacional também espera e depende de uma certa complementaridade por parte dos Estados, para que estes apliquem a jurisprudência internacional sobre os indivíduos. O sistema kelseniano se fecha de modo coerente quando se leva em conta que o Estado, única instância capaz de aplicar normas jurídicas aos indivíduos, é justamente quem delibera, juntamente com seus pares, tais normas jurídicas internacionais. Em suma, segundo Kelsen, é o direito internacional que define as esferas temporal e espacial onde serão válidas as diferentes ordens jurídicas nacionais. Kelsen rejeita assim a concepção de uma soberania estatal optando, ao invés disso, pela primazia do direito internacional.

Outra concepção célebre que defende o direito em detrimento da coerção é a de Edgar Bodenheimer (1908-1991). Esse autor define o poder como sendo a capacidade de um indivíduo ou um grupo levar adiante sua

\footnotetext{
${ }^{30}$ KELSEN, 2000, p. XXXI, pp. 462-3, e cap. VI.
}

vontade, apesar da resistência de outros indivíduos ou grupos ${ }^{31}$. Haveria, segundo Bodenheimer, duas formas extremas na vida social humana nas quais o poder seria levado às suas consequências últimas. De um lado a anarquia, situação onde todos os membros da sociedade possuem poder ilimitado. Dada a desigualdade entre os homens, e a ausência de uma bondade natural intrínseca, tal situação anárquica favoreceria enormemente o domínio dos mais fortes sobre os mais fracos. No extremo oposto, como outro cenário de uso ilimitado do poder, e talvez como consequência da anarquia, Bodenheimer vislumbra o despotismo, onde um só detém poder ilimitado sobre os que estão sob seu jugo ${ }^{32}$.

Como um meio termo entre os dois extremos da anarquia e do despotismo Bodenheimer situa o direito. Com sua faceta de direito privado o direito evita o poder ilimitado por parte dos atores individuais singulares, e com sua faceta de direito público evita o poder ilimitado por parte do governo.

Nesse sentido a função do direito não é retirar totalmente a autonomia dos atores privados ou do governo, mas apenas restringir seu raio de ação. $\mathrm{O}$ autor sugere o poder puro e o direito puro como dois polos opostos, com uma gradação de situações intermediárias entre eles, onde estariam situados diferentes sistemas sociais. O direito sugerido por Bodenheimer parte do polo do direito puro, indo em direção ao poder puro ${ }^{33}$.

Por meio desse artifício de gradação, que é conjuntural - ou seja, diferente em cada caso concreto -, o autor considera ilusórias as propostas de se tomar o direito como sendo submetido ao Estado, o Estado como submetido ao direito, ou de se tomar ambos como diferentes aspectos de uma mesma realidade, com valor idêntico. Segundo Bodenheimer, a relação entre Estado e direito é diferente em cada caso observável, conforme as formas sociais concretas tendam mais para o polo do direito puro ou da pura coerção. Ao mesmo tempo sua construção teórica o possibilita conferir a todo Estado "civilizado" o status de soberano, na medida em que constitui o órgão supremo de coordenação jurídica ${ }^{34}$.

\footnotetext{
${ }^{31}$ BODENHEIMER, 1946, p. 20.

${ }^{32}$ BODENHEIMER, 1946, pp. 23-8.

${ }^{33}$ BODENHEIMER, 1946, pp. 29-43.

${ }^{34}$ BODENHEIMER, 1946, pp. 63-78.
} 
Deixando o ponto de vista do direito e passando agora para a perspectiva da coerção, o autor mais marcante - e talvez polêmico - do século XX foi provavelmente Carl Schmitt (1888-1985). Dentro da tradição de Maquiavel e de Hobbes, Schmitt pensa a teoria política segundo critérios de razão e de tecnicidade, galgando uma posição autônoma com relação ao direito, à jurisprudência e à moral. Schmitt entende que, após Maquiavel, a política visa especificamente fins e não valores, e estuda as consequências desse desenvolvimento no surgimento do Estado e na concepção de ditadura ${ }^{35}$.

Schmitt acredita que é no estado de exceção - por excelência, na ditadura - que se revela quem realmente domina o Estado, porque é então que se descortina quem de fato pode declarar a exceção e quem de fato pode retomar a normalidade. Schmitt identifica dois tipos de ditadura: a comissária e a soberana. A ditadura comissária, sentido original de ditadura, refere-se à suspensão temporária da validade da constituição, com o intuito de facilitar uma reforma do Estado ou a superação de alguma crise - em suma, suspende-se a constituição por um tempo limitado, tendo em vista uma certa finalidade. Nessa situação o ditador é no fundo um comissário do verdadeiro soberano, com poderes supralegais durante o período de exceção, mas ainda dentro de uma certa legalidade, ao menos enquanto dura seu mandato ${ }^{36}$. A ditadura soberana, por sua vez, constitui um problema de soberania, e não uma mera questão de governo. A diferença com relação à anterior é que nesta o ditador é o próprio soberano, e encontra-se dotado de poder para reformar a organização estatal constituída. Assim, para ser caracterizada como soberana, uma ditadura precisa fundar-se em uma finalidade que se encontre fora do ordenamento constituído, implicando em um reordenamento deste. Mais precisamente, conforme Schmitt, implica na existência de um inimigo a ser eliminado, seja ele um invasor externo ou uma situação de poder interna ${ }^{37}$. Assim, para Schmitt, a soberania se constitui de fato, na realidade concreta do jogo de poder. É soberano quem domina o Estado, ou seja, quem decide sobre o estado de exceção, decidindo quando este deve existir e o que é que exige a situação concreta ${ }^{38}$.

\footnotetext{
${ }^{35}$ SCHMITT, 1985, pp. 40-4

${ }^{36}$ SCHMITT, 1985, cap. 1

${ }^{37}$ SCHMITT, 1985, cap 3

${ }^{38}$ SCHMITT, 1985, p. 49.
}

Um segundo autor que se atém ao polo da coerção, ou mais especificamente ao modo como as coisas são em oposição ao ponto de vista ideal do direito, é Hermann Heller (1891-1933). Heller, assim como Kelsen, escreve no primeiro pós- guerra. Mas enquanto Kelsen propõe um direito internacional puro e abstrato, desvinculado das particularidades estatais, e que obrigaria os Estados por ser-lhes anterior, Heller propõe os Estados soberanos como unidades fundamentais e constituintes do direito internacional, portanto anteriores a ele.

Para Heller o direito internacional é uma convenção entre unidades soberanas, é uma reunião de unidades de vontade autônomas. Nenhuma dessas unidades está obrigada a firmar tratados com as outras, mas, na medida em que o faça, submete-se às regras objetivadas e a uma relação de subordinação. Mas em todo caso a única limitação a que o Estado se submete é àquela acatada pela própria vontade soberana. Assim, se em algum sentido o direito internacional constrange o Estado, é apenas porque este consente em que isso ocorra.

O soberano de Heller é livre internamente para romper e recompor o ordenamento jurídico quando necessário, e externamente para contratar em seus próprios termos. As prescrições do direito internacional só têm validade interna quando são introjetadas no Estado pelo soberano, que é o único capaz de validar a norma e viabilizar sua reforma. É duvidoso, portanto, pensar que o direito internacional limita a soberania estatal. Enquanto o direito internacional é a união das vontades às quais se destinam as normas, o direito estatal (ou direito interno) é imposto pelo soberano àqueles a quem as normas se destinam. Heller considera direito somente as normas positivas, que são normas que se referem especificamente à comunidade determinada à qual se aplicam, conforme as peculiaridades desta, e nela fazem sentido. Além disso o direito, segundo Heller, é algo estabelecido pela autoridade da própria comunidade, visando limitar normativamente sua própria conduta externa. O soberano é, portanto, a parcela da comunidade que tem o poder de positivar as normas, de reconhecer sua correspondência com a realidade do Estado, e a partir daí conferir-lhes validade.

A positividade do direito interno pode ser entendida, em Heller, como sendo a expressão do passado do corpo social, que quer se perpetuar no presente e se projetar no futuro, mas que o soberano corre sempre para 
modificar e atualizar ${ }^{39}$. Sob esse ponto de vista o direito de Heller é a expressão de uma vontade, e portanto marca a recuperação da pessoa a que se refere o direito, um sujeito que o direito abstrato de Kelsen ignora. O sujeito que Heller aponta como independente e portador de uma vontade própria é justamente a vontade geral ${ }^{40}$, capaz de positivar as normas e de assumir o papel de soberano.

Sob essa ótica a soberania estatal de Heller nada mais é do que a expressão da realidade da comunidade. Heller, seguindo a trilha de Harold Laski, reconhece o papel do povo na tomada de decisões ${ }^{41}$. Laski rejeita um monismo social radical, divinizador do Estado, segundo o qual a totalidade seria portadora de um interesse próprio que transcende o interesse de seus componentes. Ou seja, afirma que, se determinada resolução estatal conta com o apoio do povo ao qual ela se refere, isso se deve à coincidência - ou à não confrontação direta - dos interesses de ambos. Mas ao contrário de Laski, que reconhece o papel do povo mas não se decide quanto ao locus da soberania, Heller atribui ao próprio povo o poder soberano.

Não se pretende de forma alguma resolver essa vasta discussão entre coerção e direito. Mas cabe ainda analisar o pensamento de Francis Harry Hinsley (1918-1998), que tende a sugerir uma acomodação entre coerção e direito no que concerne à problemática da soberania. Tal acomodação parece satisfatória do ponto de vista teórico (ainda que de forma alguma conclusiva), e operacional do ponto de vista prático. Hinsley parte da origem dos conceitos de Estado e soberania, e a partir daí enfoca a distinção entre a comunidade e seu governo. Tal distinção, que Heller havia usado para fortalecer a concepção clássica de soberania, é importante para Hinsley na medida em que possibilita ao governo deixar de ser uma instituição submetida às leis para se tornar ele próprio a lei encarnada. Essa evolução teria ocorrido paralelamente ao distanciamento entre lei positiva e lei divina: o governo da comunidade, ainda que continue submetido às leis do segundo tipo, torna-se superior à lei positiva. Essa diferenciação é que permite o surgimento da soberania, reguladora dos conflitos entre comunidade e governo. No início ela é um atributo apenas do monarca, mas mais tarde, quando está prestes a passar para as mãos do povo, monarca e

\footnotetext{
${ }^{39}$ DE LA CUEVA, Mario: "Estudio Preliminar”, in HELLER, 1995.

${ }^{40}$ No original, volonté générale (livre-tradução). HELLER, 1995, pp. 193-4.

${ }^{41}$ LASKI, 1937, cap. I.
}

povo são surpreendidos com o advento da soberania do Estado. Isso significa que ambos, governantes e governados, passam a submeter-se à figura abstrata do Estado. Essa seria a única forma encontrada, segundo Hinsley, para conciliar governantes e governados sem prender o conceito de soberania a uma instituição física, ou sem ter que negar sua existência ${ }^{42}$.

A soberania denota, segundo Hinsley, a existência de uma autoridade final e absoluta dentro da comunidade política, e de nenhuma outra autoridade desse tipo mais além. Nesse sentido soberania não é um fato, e sim um conceito. É uma forma de conceber e de explicar o poder político, dando ao governo um critério de legitimação e alguma responsabilidade. De acordo com Hinsley a soberania só se desenvolve quando os resquícios de segmentaridade são suficientemente superados dentro do Estado, quando este conta com um poder central unitário e bem estabelecido. Um Estado só deixa de ser segmentário quando uma parcela suficiente da população o aceita e, a partir daí, ele passa a mudar suas perspectivas em função das necessidades e exigências da comunidade. Em outras palavras, a soberania só surge quando a comunidade e seu governo - ou, a sociedade e o Estado são distintos, mas em certa medida integrados.

Hinsley considera um erro tratar a soberania como uma medida do que o Estado ou a sociedade fazem ou podem fazer. A soberania é apenas uma ideia, uma construção teórica e necessária, que afirma que deve haver uma autoridade suprema dentro da comunidade política, para que essa possa existir e atuar como exigem seu caráter e as circunstâncias atuais ${ }^{43}$. Mas mesmo sendo uma construção a soberania é a condição essencial para a participação na comunidade internacional. Quanto mais se integra essa comunidade mais poder adquire o Estado, e mais importância recebe a soberania. Como decorrência disso, mais se estreita a associação entre comunidade nacional e Estado.

Concebendo assim a soberania como uma construção arbitrária e necessária, a teoria de Hinsley parece conseguir combinar singularmente a sociedade e seu governo. Em outras palavras, Hinsley oferece uma solução interpretativa que possibilita recombinar as esferas da positividade e da normatividade.

\footnotetext{
${ }^{42}$ HINSLEY, 1972, pp. 135-6.

${ }^{43}$ HINSLEY, 1972, p. 187.
} 


\section{MUdANÇA OU CONTINUIDADE?}

\section{CONCEPÇÕES DE SOBERANIA NO PÓS-GUERRA FRIA}

Tendo passado pelo surgimento e pelo desenvolvimento da concepção clássica de soberania, segundo Bodin e Hobbes e através de autores mais modernos (Kelsen, Bodenheimer, Schmitt, Heller e Hinsley), cabe agora verificar se esse conceito permanece válido no presente e se há em vista perspectivas de que se altere dentro de um futuro previsível. O final da Guerra Fria muda muita coisa nas relações internacionais. Dada a polarização entre as duas superpotências, que domina todo o cenário internacional do segundo pós-guerra, o modelo das Nações Unidas é poupado de provar sua eficiência prática. No plano da força todas as querelas entre os Estados acabam se transformando em simples expressões contingentes de uma divisão de mundo estrutural. No plano do direito o Conselho de Segurança da ONU esteve tomado por uma paralisia decisória causada pela relutância de negociação entre Estados Unidos e União Soviética. Com a queda do Muro de Berlim (1989), a derrocada da URSS (1991) e um sentimento geral de vitória dos EUA sobre o comunismo, o caminho se abre novamente para que as relações internacionais possam seguir seu curso.

Se durante esse meio século as relações internacionais evoluíram em um ritmo relativamente lento, mudanças rápidas e sem precedentes tiveram lugar em outros campos. Por exemplo, ganham força as ideias de um mundo pela primeira vez totalmente interligado, com bens e informações sendo trocados por todo o globo a grande velocidade e de forma constante. Até que ponto essa foi uma mudança qualitativa, ou se foi apenas uma intensificação se é que foi - de fenômenos já presentes há muito, não cabe aqui discutir. $\mathrm{O}$ que interessa a este trabalho é em que medida e de que forma as relações internacionais - mais especificamente o conceito de soberania no âmbito externo - reagiram a essas supostas mudanças.

Gene Lyons e Michael Mastanduno apontam, em um trabalho editado em 1995, que tais mudanças têm se expressado, no sistema internacional, na extensiva participação dos Estados em organizações internacionais ${ }^{44}$. Por meio dessa participação os Estados passam, por exemplo, a aceitar práticas comerciais em comum, a adotar medidas de proteção ambientais, e a se comprometer com o direito dos cidadãos às liberdades fundamentais. Tais

\footnotetext{
${ }^{44}$ LYONS \& MASTANDUNO, in LYONS \& MASTANDUNO (eds.), 1995, p. 15
}

mudanças refletiriam metamorfoses políticas e econômicas, e culminariam com a transformação do sistema internacional em uma sociedade internacional - ou seja, na aceitação, por parte dos Estados soberanos, de normas compartilhadas e reconhecidas mutuamente. Tais mudanças, para Lyons e Mastanduno, teriam sido gestadas dentro de uma ordem "estadocêntrica" que remontava à organização internacional vigente desde o Tratado de Westfália, de 1648. Mas, segundo eles, em que medida tais mudanças não representariam uma alteração qualitativa nas relações de autoridade entre os Estados e a comunidade internacional ${ }^{45}$ ? Em que medida a soberania estatal fica abalada por pretensões de uma ordem internacional superior ao Estado? Citando os autores, "Estamos, com efeito, indo para além de Westfália?"46. A seguir, os posicionamentos de alguns dos autores apresentados por Lyons e Mastanduno.

Nicholas Onuf adota uma abordagem que ele chama construtivista ${ }^{47}$ Nessa abordagem indivíduo e sociedade se construiriam reciprocamente, nenhum dos dois sendo anterior ao outro, e ambos existindo apenas em conjunto. Tal raciocínio pode ser aplicado tanto às comunidades políticas (Estados) quanto às comunidades supraestatais. Os feitos (deeds) individuais constituiriam as sociedades, e estas, por meio de regras (rules), balizariam esses feitos ${ }^{48}$. Para o autor, o fato da soberania estatal estar aparentemente perdendo coerência seria devido a recentes alterações nas regras de admissibilidade das intervenções internacionais. As alterações nessas regras seriam a expressão de uma mudança de proporções epocais, baseada na atual conduta dos indivíduos, expressando mudanças importantes na sociedade internacional. Onuf está longe de propor uma perda de centralidade dos Estados como atores relevantes na sociedade internacional - afinal, são eles que ligam os indivíduos à terra. Por outro lado, o que sustenta é que o bem comum, objeto último da intervenção internacional, deixa de ser responsabilidade exclusiva dos Estados, e passa a ser objeto também de instâncias que se pretendem superiores ${ }^{49}$.

${ }_{45}^{45}$ LYONS \& MASTANDUNO, in LYONS \& MASTANDUNO (eds.), 1995, p. 15. ${ }^{46}$ LYONS \& MASTANDUNO, in LYONS \& MASTANDUNO (eds.), 1995, p. 15; livre-

${ }_{47}^{\text {tradução. }}$ No original, constructivism; livre-tradução. ONUF, in LYONS \& MASTANDUNO (eds.), 1995 , p. 44

${ }^{48}$ ONUF, in LYONS \& MASTANDUNO (eds.), 1995, pp. 44-5; livre- tradução dos termos originais.

${ }^{49}$ ONUF, in LYONS \& MASTANDUNO (eds.), 1995, p. 58 
Um caminho semelhante ao de Onuf é o percorrido por Robert Jackson. Partindo de um ponto de vista mais ligado ao direito, Jackson pressupõe a existência e validade de uma lei internacional, e a partir desta define a soberania como sendo não apenas a prerrogativa estatal de autonomia, mas também o dever de respeito à autonomia alheia ${ }^{50}$. As diversas unidades estatais estariam assim obrigadas à coexistência segundo as leis da comunidade internacional. Porém, mais além dessa comunidade internacional formada pelos Estados e seus cidadãos, Jackson supõe a existência de uma comunidade da humanidade, da qual todo homem é membro independente de sua condição dentro de um Estado. Tal diferenciação é fundamental para compreender a legalidade e a legitimidade das intervenções internacionais. Atualmente, como os Estados e cidadãos é que são os portadores de direitos e deveres na comunidade internacional, Jackson julga moralmente necessário que se justifiquem as intervenções internacionais. Caso a comunidade internacional e a comunidade da humanidade coincidissem, os portadores de direitos e deveres seriam os seres humanos, e nesse caso a ausência de intervenção é que precisaria ser justificada $^{51}$. Mais uma vez, porém agora de forma velada, aparece a concepção de que as intervenções internacionais se dão visando algum bem coletivo praticado em nome da humanidade.

James Rosenau encara de frente a questão da atualidade ou inadequação do conceito de soberania, e tenta conciliar termos aparentemente contraditórios como a interdependência entre os Estados e sua autonomia ${ }^{52}$. O que esse autor propõe é que se deixe de lado a visão dicotômica de soberania versus intervenção, e que se adote no lugar a ideia de um continuum entre dois extremos, sem que um seja moralmente superior ao outro. Um desses extremos seria a soberania, esfera de autonomia estatal reconhecida pelos princípios da lei internacional. Nessa esfera fica vetada qualquer tentativa de intervenção internacional. $\mathrm{O}$ outro extremo seria o espaço da não soberania, na qual, não havendo autonomia exclusiva de nenhuma unidade, seriam possíveis intervenções segundo a lei internacional. Essa situação torna-se visível, segundo Rosenau, pela conduta dos Estados nas relações internacionais. Se tais condutas se

\footnotetext{
${ }^{50}$ JACKSON, in LYONS \& MASTANDUNO (eds.), 1995, pp. 61-2.

${ }^{51}$ JACKSON, in LYONS \& MASTANDUNO (eds.), 1995, p. 80.

${ }^{52}$ ROSENAU, in LYONS \& MASTANDUNO (eds.), 1995, p. 195.
}

apresentam atualmente como mais inovadoras do que no passado, isso se deve ao fato de estarem expressando mudanças profundas nos sustentáculos da política mundial - resultado do fim da Guerra Fria e do colapso da União Soviética. Rosenau observa grandes transformações ocorrendo ao mesmo tempo nos três parâmetros centrais de toda ordem global: as estruturas totalizantes da política global, as estruturas de autoridade que ligam as coletividades e os cidadãos, e as habilidades dos cidadãos ${ }^{53}$. Como decorrência das transformações nesses três níveis o autor propõe um movimento, ao longo do continuum de soberania, em direção ao extremo da não soberania e da intervenção. Trata-se, segundo Rosenau, de um movimento irreversível. Mas também lhe parece pouco provável que o polo da não soberania seja plenamente atingível - ao menos em um futuro previsível. As apostas de Rosenau vão no sentido de uma nova ordem internacional caracterizada por uma constante tensão entre os dois polos, revelando-se numa disputa duradoura entre soberania e intervençã ${ }^{54}$.

Com base nesses pontos principais Lyons e Mastanduno sugerem, a título de conclusão, que o conceito de soberania não pode, ao menos por enquanto, ser descartado. Eles retiram, dos ensaios exposto, quatro observações que lhes parecem fundamentais ${ }^{55}$. Em primeiro lugar, parecelhes que os constrangimentos à soberania estatal, apesar de sua longa história, tornam-se cada vez mais significativos na atualidade, dado o crescente processo de interdependência entre os Estados e o final da Guerra Fria. Segundo, tais constrangimentos à soberania estatal não diriam mais respeito somente à conduta externa dos Estados, mas também a questões internas como cidadãos, economia e território. Em terceiro lugar notam que a comunidade internacional desenvolveu forte presença institucional, ainda que lhe faltem recursos e capacidade organizacional para que possa constituir uma alternativa viável à sociedade de Estados soberanos. E, por último, dizem que a legitimidade da comunidade internacional continuará sendo questionada enquanto houver diferenças entre os interesses que ela deva representar - sendo mais marcantes, atualmente, as diferenças entre Norte e Sul do globo. Baseados nessas constatações, os autores propõem uma escala de justificações para a intervenção internacional, indo do realismo puro ao

${ }^{53}$ ROSENAU, in LYONS \& MASTANDUNO (eds.), 1995, pp. 203-4

${ }^{54}$ ROSENAU, in LYONS \& MASTANDUNO (eds.), 1995, pp. 225-7.

${ }^{55}$ LYONS \& MASTANDUNO, in LYONS \& MASTANDUNO (eds.), 1995, p. 252 22 
globalismo puro $^{56}$. Eles não negam a possibilidade de que o sistema internacional esteja transitando da base para o topo dessa escala; mas afirmam que não se pode dizer que uma mudança irreversível já tenha se operado.

Apesar das particularidades de cada um desses pontos de vista, parece possível agrupar todos sob um mesmo rótulo abrangente "transicionistas"? -, já que para todos, grosso modo, é plausível a ideia de que a soberania estatal esteja sendo - ou possa vir a ser - substituída por normas internacionais vinculantes. Desse ponto de vista Stephen D. Krasner parece destoar dos demais autores do pós-Guerra Fria aqui visitados. Os próprios editores dos ensaios, Lyons e Mastanduno, parecem não ter dado atenção, ou terem considerado de menor importância, o fato de Krasner se posicionar diametralmente contra a ideia de uma ruptura com o conceito tradicional de soberania, ou mesmo de uma transição suave deste para um sistema internacional que justifique normativamente a intervenção internacional $^{57}$. Segundo Krasner, se por um lado é verdade que o realismo não explica satisfatoriamente a intervenção, por outro lado também é verdade que as supostas mudanças da atualidade não são suficientes para descartá-lo.

Krasner acredita que o realismo não tenha como foco de sua análise a não intervenção, e sim a autonomia ${ }^{58}$ estatal. Teorizar sobre restrições à intervenção iria, portanto, diretamente contra esse preceito. A saída encontrada pelos realistas parece ser o reconhecimento de que intervenções ocorrem na prática. Mas essa é uma saída duvidosa, na medida em que implica a aceitação de que as unidades soberanas - ou ao menos algumas delas - não são assim tão soberanas quanto o realismo gostaria. Para Krasner esse reconhecimento é um preço barato a ser pago pela prova empírica de que a autonomia estatal prevalece sobre o princípio da não intervenção. Essa prova o autor deriva da análise de várias realidades históricas: as questões religiosas (resolvidas pelo Tratado de Westfália), tratados de minorias (no século XIX e no primeiro pós-guerra), tratados anti- escravidão (no século XIX), e em outros estudos de caso. Em todos esses exemplos Krasner constata que os Estados mais poderosos impunham comportamentos (como a tolerância religiosa, ou o respeito às minorias

\footnotetext{
${ }^{56}$ LYONS \& MASTANDUNO, in LYONS \& MASTANDUNO (eds.), 1995, p. 260 e segs.

${ }^{57}$ KRASNER, in LYONS \& MASTANDUNO (eds.), 1995.

${ }^{58}$ No original, self-help; livre-tradução. KRASNER, in LYONS \& MASTANDUNO (eds.), 1995, p. 232.
}

nacionais) aos Estados mais fracos, mas reservavam para si e para seus pares uma autonomia absoluta nessas questões. Isso significa que a intervenção ocorre por interesses internos do Estado interventor, e não por fatores sistêmicos. Para Krasner isso é o suficiente para o reconhecimento de que a prática das relações internacionais permanece a mesma há séculos.

Krasner desenvolve essas ideias em um estudo posterior, Sovereignty - organized hypocrisy ${ }^{59}$. Três pontos desse estudo merecem destaque. Inicialmente, o autor distingue quatro acepções diferentes do termo soberania: soberania legal internacional (international legal sovereignty - o reconhecimento mútuo de independência jurídica por parte das unidades do sistema internacional), soberania de Westfália (Westphalian sovereignty - a exclusão dos atores externos das estruturas de autoridade de determinado território), soberania doméstica (domestic sovereignty - a capacidade de controle interno), e soberania de interdependência (interdependence sovereignty - o controle do fluxo de bens, pessoas, ideias, etc. nas fronteiras). Embora Krasner trate especificamente da soberania em suas duas primeiras acepções, deixa claro que a vantagem dessa divisão é distinguir entre diferentes modalidades de poder soberano, e que o enfraquecimento de um tipo de soberania não significa necessariamente o enfraquecimento dos demais ${ }^{60}$.

Em segundo lugar Krasner distingue entre uma lógica das consequências e uma lógica da adequação, ou seja, entre ações que se pautam pelos resultados esperados, ou pela adequação da conduta às regras do jogo e ao papel que o ator ocupa ${ }^{61}$. Krasner foca seu trabalho no papel dos governantes enquanto atores que buscam o poder e que, uma vez alcançado esse objetivo, buscam a segurança, a prosperidade e os valores morais de quem o apoia - seja o povo ou uma guarda pessoal restrita. Desse ponto de vista Krasner sugere que os governantes atuam segundo a lógica das consequências, respeitando ou não a soberania alheia conforme seus próprios interesses.

Em último lugar convém citar que, embora Krasner se proponha a analisar a vida social de uma perspectiva orientada por atores, sua proposta também é adequada a uma perspectiva sociológica, isto é, ao ponto de vista

\footnotetext{
${ }^{59}$ KRASNER, 1999.

${ }^{60}$ Livre-tradução dos termos. KRASNER, 1999, pp. 3-5 e pp. 9-25.

${ }^{61}$ No original, logic of consequences e logic of appropriateness (livre- tradução). KRASNER, 1999, pp. 5-7.
} 
das instituições e das normas compartilhadas. O que o autor sugere é que sua interpretação do modelo de Westfália, ainda que se caracterize por um baixo grau de institucionalização (isto é, de conformidade entre as normas e os comportamentos), conta com um elevado grau de persistência das normas em condições cambiantes. Assim a conduta interessada dos atores coexistiria com normas duradouras de convívio internacional - ainda que estas últimas nem sempre sejam respeitadas pela primeira ${ }^{62}$.

Em suma, Krasner nega qualquer diferença fundamental entre a atualidade das relações internacionais e seu passado. A não intervenção teria sido sempre um princípio aceito, mas invariavelmente transgredido, pois o grau de institucionalização das normas depende do poder e dos interesses dos governantes. Quando defrontados com novos problemas, estes simplesmente criariam regras novas. Assim o modelo de Westfália, em vigência tanto na atualidade quanto nos últimos séculos, seria um exemplo do que Krasner chama de hipocrisia organizada ${ }^{63}$.

Parece, em retrospectiva, que o tema da soberania está longe de ser descartado do rol de preocupações das Relações Internacionais contemporâneas. Ora resgatada, ora condenada, a soberania estatal permanece no centro da discussão, e em seu cerne continua vivo o jogo de acomodações entre direito e coerção. Com essas constatações em vista o próximo capítulo tentará trazer à tona a problemática da intervenção, que é o reverso da moeda da soberania. O capítulo será centrado, mais especificamente, em um tipo peculiar de intervenção internacional: aquela que é exercida tendo como pretexto preocupações ambientais. Esse é um passo necessário para que seja possível, em seguida, pensar acerca de um eventual posicionamento brasileiro com respeito à Amazônia.

\footnotetext{
${ }^{62}$ KRASNER, 1999, p 58 e segs.

${ }^{63}$ No original, organized hypocrisy; livre-tradução. KRASNER, 1999.
}

\section{CAPÍTULO 2}

\section{DA INTERVENÇÃO AMBIENTAL À INGERÊNCIA ECOPOLÍTICA}

Se por um lado não se obteve até aqui nenhuma conclusão definitiva a respeito do conceito de soberania, por outro lado espera-se ter apresentado um panorama elucidativo de uma tensão interna constitutiva desse conceito. Tal tensão, entre os polos do direito e da coerção, reaparece na questão da intervenção internacional. Se a soberania estatal for considerada como sendo a esfera de validade do direito de um Estado, a intervenção aparece como um direito que se pretende superior ao do Estado; se a soberania for considerada como a esfera onde o Estado exerce sua capacidade de coerção, a intervenção toma a forma de uma força real externa superior à estatal. Em ambos os casos a intervenção constitui uma forma de antítese da soberania, de uma modalidade que age sobre o Estado especificamente a partir de seu exterior. A afronta que a intervenção apresenta à soberania estatal é clara: pressupõe sempre a existência de uma instância superior ao Estado, seja na forma de uma maior eficácia no uso da coerção, seja na forma de uma ordem normativa que se pretende última e mais abrangente.

A problemática da intervenção internacional é trazida à tona juntamente com a emergente questão ambiental. Este é o enfoque elegido por este trabalho para tratar da primeira. O presente capítulo deverá ocuparse, portanto, da intervenção ambiental propriamente dita, de suas formas e de suas implicações para o sistema internacional. Antes, entretanto, é necessário falar mais especificamente sobre o meio ambiente, e de sua escolha como objeto deste trabalho. Também é necessário justificar essa escolha, e provar que ela é no mínimo tão boa quanto qualquer outra possível para tratar dos temas da soberania e da intervenção. Deverá ficar claro que a questão ambiental, em toda sua complexidade, se presta a trabalhar a temática da intervenção versus a soberania estatal, e que ao mesmo tempo serve como modelo para o entendimento dessa dicotomia em outros campos, como os direitos humanos e a segurança global - para citar apenas os de maior destaque. 


\section{DEBATE ECOLÓGICO E ECOPOLÍTICA}

Segundo o Dicionário de Política é certa a existência de um nexo entre política e ecologia ${ }^{64}$. A primeira trata de comportamentos socialmente organizados, que são parte dos comportamentos da espécie humana, enquanto a segunda trata do sucesso evolutivo das espécies viventes conforme sua capacidade de adaptação ao meio no qual se encontram inseridas. Assim sendo a política pode ser entendida como uma espécie de caso particular da ecologia; do mesmo modo os processos ecológicos talvez possam ser encarados como uma extrapolação (uma modalidade mais abrangente) dos processos políticos.

A ecologia não trata somente da adaptação dos seres ao meio. Mais do que isso, trata do próprio meio no qual os seres vivos estão inseridos. Os seres vivos também exercem influência, em maior ou em menor grau, sobre seu habitat; trata-se de uma via de mão dupla. Sofrendo a ação do meio e ao mesmo tempo agindo sobre ele, uma atitude razoável para as espécies viventes seria atuar sobre seu entorno de modo a adaptá-lo às suas necessidades, tornando-o mais suportável e mais adequado à sua sobrevivência. Uma das formas de atuação do homem sobre seu meio, à qual o presente estudo diz respeito, passa pelo exercício do poder. Em outras palavras, a política pode ser vista como um instrumento de atuação do homem sobre o meio.

Disso resulta que seria racional para a espécie humana, em todas as suas formas de atuação - e, como ficará claro, mais especificamente na atuação política -, zelar pelo meio ambiente, evitando seu desgaste e degradação, e garantindo às gerações futuras a possibilidade de sobrevivência e de reprodução da espécie. Hoje em dia, como vem sendo difundido pela mídia, é no mínimo duvidoso que o homem esteja agindo segundo essa lógica de sobrevivência. O modo como essa atuação vem se dando é preocupante, e é o foco da discussão que se desenvolve a seguir.

Philippe Le Prestre estuda as relações entre homem e natureza, e as encontra, recentemente, divididas em três fases ${ }^{65}$. Durante a primeira fase, do fim do século XIX até 1968, a preocupação ecológica estaria totalmente

\footnotetext{
${ }^{64}$ CONTI, 1986, p. 976.
}

${ }^{65}$ LE PRESTRE, 2000, Cap. 5. submetida ao pensamento econômico, ou seja, o meio ambiente era visto como uma simples fonte de recursos para o desenvolvimento material. É bem verdade que após 1945 o mesmo espírito de cooperação internacional que fundava a ONU permeava também a questão ambiental. Mas esse espírito era apenas a manifestação de uma preocupação, compartilhada pelos países industrializados, acerca do uso racional de recursos naturais escassos.

A segunda fase teria início em 1968, e duraria até 1986. Nesse período as questões ambientais emergem no primeiro plano das relações internacionais, tanto nos países desenvolvidos quanto nos países em desenvolvimento. A questão não era mais determinada espécie, paisagem ou recurso natural considerados individualmente, e sim o impacto da atividade humana sobre o todo. Passava-se então para uma visão mais abrangente, cujo centro era o meio ambiente como totalidade. O rápido crescimento econômico dava cada vez mais visibilidade aos problemas ambientais. A cooperação científica também crescia, especialmente nas suas formas internacional e não governamental. Os atores envolvidos aumentavam em número, e eram cada vez mais presentes as modalidades de militância. O ponto alto dessa fase foi a Conferência de Estocolmo, em 1972. Foi aí que o problema ambiental foi finalmente reconhecido, e percebeu-se a necessidade de agir. Os países menos desenvolvidos, que até então se preocupavam apenas com seu direito ao desenvolvimento através do uso dos recursos naturais, também se sensibilizaram, e iniciou-se o planejamento de um guia coletivo para a ação futura.

Apesar de todos os esforços a Conferência de Estocolmo apresentava alguns problemas. O conhecimento científico, por mais desenvolvido que fosse, permanecia no fundo incerto, e os custos de implementação dos planos de ação eram altíssimos; em suma, os fins almejados eram irrealistas. E ainda, quanto aos princípios, defendia-se o meio ambiente não por qualquer valor intrínseco que este pudesse ter, e sim pelo próprio bem do homem, para que este não perecesse por seus excessos. Tudo isso deu uma aparência de desgaste à Conferência, mas por fím seus valores conseguiram consolidar-se.

Em 1987 teria início a terceira fase das relações entre homem e natureza. Os anos 1980 assistiam a um retorno vigoroso das questões ambientais, com a multiplicação das ONG's e a diminuição da importância dos temas de segurança global (dado o final da Guerra Fria e as políticas de 
redução de armas estratégicas das superpotências). Novos princípios jurídicos favoreciam a defesa internacional do meio ambiente, e o Banco Mundial adota sua política ambientalista. Como ponto chave desse ressurgimento está a publicação do Relatório Brundtland (sobre a Conferência de Estocolmo), que inova enormemente ao conciliar meio ambiente e desenvolvimento em uma política de "desenvolvimento durável" - ou, desenvolvimento sustentável. Conservação ambiental não excluía mais necessariamente a possibilidade de desenvolvimento. Tornavase então possível que os países chamados subdesenvolvidos concordassem com os desenvolvidos em cuidar do meio ambiente, sem que isso lançasse por terra suas esperanças de desenvolvimento. Ainda que nada pudesse garantir o consenso entre os países desenvolvidos e subdesenvolvidos, já se podia contar com linhas gerais de conduta a serem seguidas.

Na Conferência do Rio, em 1992, a reconciliação entre meio ambiente e desenvolvimento é ratificada, e uma solidariedade internacional inédita se inicia por meio de responsabilidades comuns, ainda que diferenciadas, entre os países desenvolvidos e os países em desenvolvimento. Ambas as partes se comprometem com a preservação ambiental, e os primeiros admitem sua parcela de culpa ecológica, prometendo auxiliar no desenvolvimento "limpo" dos segundos. O meio ambiente finalmente se torna uma preocupação comum da humanidade, e aspectos antes limitadores como o alto custo dos projetos e a incerteza científica deixam de servir como desculpa para atitudes antiecológicas. É claro que a observação da Agenda 21 proposta no Rio, bem como uma apreciação equilibrada das prioridades do meio ambiente e do desenvolvimento, constituem desafios para os atores. Mas Le Prestre acredita que

A institucionalização do ambientalismo é talvez agora suficiente para que todo progresso na cooperação não seja mais totalmente dependente das flutuações do interesse público e dos governos. ${ }^{66}$

A reconstrução histórica de Le Prestre é suficiente para os fins deste trabalho, e não é necessário entendê-la em pormenor. Mas também é interessante dar uma passada de olhos pelas concepções que outros autores têm da história das relações do homem com a natureza. Michel Bachelet, por exemplo, apregoa que

\footnotetext{
${ }^{66}$ LE PRESTRE, 2000, p. 199.
}

Inicialmente divinizada, depois explorada e, por fim, alienada, a Terra conhecerá depois dessas três eras a era do respeito, utilitária é certo, mas favorável à prossecução da aventura humana. (...) Será a ingerência ecológica um desses novos meios que o homem deveria inventar para reduzir, minorar, e até parar, pelo menos em caso de risco maior, a sua bulimia suicidária de consumidor desenfreado da natureza? $?^{67}$

Daniel Deudney vai além, e considera a "cultura verde" como destinada a suprir necessidades psíquicas e culturais da humanidade, necessidades estas antes supridas pela religião, e atualmente parcialmente supridas pelo nacionalismo. Para Deudney o ambientalismo forneceria ao homem de hoje uma cosmologia própria, da qual este necessita e que é aceitável atualmente ${ }^{68}$.

Com o final da Guerra Fria Le Prestre observa o surgimento de um sistema internacional multipolar, caracterizado pelo declínio do embate ideológico Leste-Oeste e pela expansão da sociedade internacional ${ }^{69}$. Em tal contexto a ecopolítica internacional é fortemente influenciada pelo poderio econômico. Isso gera uma situação de antagonismo entre os países mais desenvolvidos e os países em desenvolvimento - ou, em termos já consagrados nas Relações Internacionais, entre os países do "Norte" e os do "Sul".

No Sul do período pós-Guerra Fria a questão ambiental ganha inegável importância, e a capacidade de desenvolvimento sustentável substitui em certa medida a ideologia como fonte de legitimidade dos governos sulistas frente ao Norte. Por outro lado, o que ocorre na prática é um aumento geral dos conflitos entre e dentro dos países do Sul, o que invariavelmente implica em agravamento da degradação ambiental. Para os países do Norte, principais senhores do capital, a ausência da bipolaridade Leste-Oeste torna menos recompensador auxiliar no desenvolvimento dos países do Sul. Esse desinteresse resulta em um certo impasse, pois, se é o Sul quem vincula com maior afã meio ambiente e desenvolvimento, quem comanda a agenda ambiental continua sendo o Norte. O antagonismo entre ambos faz com que aumente dos dois lados o uso instrumental do discurso ambientalista, o que por si só leva à politização da questão ambiental. É

\footnotetext{
${ }^{67}$ BACHELET, s.d., p. 166.

${ }^{68}$ DEUDNEY, in LIPSCHUTZ \& CONCA (eds.), 1993, Cap. 11.
}

${ }^{69}$ LE PRESTRE, 2000, Cap. 7. 
nesse contexto que Le Prestre identifica, e toma como tema de trabalho, o que chama de ecopolítica internacional. Ao ganhar esse sentido fortemente político é que o ambientalismo torna-se central no estudo das relações humanas, especialmente para a política internacional, e de forma específica no caso deste trabalho.

Bachelet acredita que o risco ecológico, antes de científico, associativo, político, industrial ou econômico, é ético e estético, e talvez cívico, categorias que buscam criar comportamentos individuais favoráveis ao grupo ${ }^{70}$. De qualquer modo, em determinado momento o sentido político aflora, e é ele que faz com que grupos diferentes (como Norte e Sul) se afastem entre si. Também Le Prestre enxerga dessa forma a cisão entre Norte e Sul, e vai mais além. Acredita que os interesses políticos geram atritos não apenas entre os blocos, mas também dentro de cada bloco. Mas tais tensões são vistas como benignas aos esforços de cooperação, já que nenhum Estado pode então ficar de fora de certas negociações, especialmente das que ameaçam lesar seus interesses particulares.

A dimensão política do ambientalismo também justifica que a ecopolítica seja tomada como o objeto deste trabalho, por conferir à questão ambiental uma posição central nas preocupações do Estado soberano. Porém, ao invés da questão ambiental em sua amplitude total, este trabalho se preocupa com a situação da soberania nacional na Amazônia brasileira, conforme será visto em detalhe no próximo capítulo. Ken Conca $^{71}$ qualifica o problema do desmatamento das florestas tropicais, e em especial da Amazônia, como um caso exemplar para o estudo das realidades e das normas ambientais emergentes, e portanto útil para a verificação das concepções e práticas do Estado brasileiro a respeito da soberania. Conca dá para isso cinco fortes motivos. Inicialmente, trata-se de um tema que combina intensos interesses locais e fortes preocupações globais sobre o estímulo ou combate à destruição florestal. Em segundo lugar envolve disputas de jurisdição, autoridade e legitimidade, expressando o conflito entre diversos interesses: organizações ambientalistas, governos de países industrializados, comunidades locais, etc. Uma terceira razão é justamente o fato de trazer à tona o debate sobre a soberania, já que as florestas tropicais, ao contrário dos oceanos ou da camada de ozônio, estão indiscutivelmente

\footnotetext{
${ }^{70}$ BACHELET, s.d., pp. 161-2.

${ }^{71}$ CONCA, in LYONS \& MASTANDUNO (eds.), 1995, Cap. 7.
}

localizadas dentro do território de Estados soberanos. Portanto as florestas tropicais seriam ao mesmo tempo propriedade de determinado Estado e da comunidade global. Outro motivo elencado é a relutância dos Estados soberanos em delegar à comunidade internacional a tutela de suas florestas. Isso mostra que, ainda que a preservação seja um interesse coletivo, existem nos bastidores interesses estatais nem sempre favoráveis a ela. Finalmente, como quinta e última razão, há a configuração que a questão toma de conflito entre Norte e Sul, polarização essa que se repetiria em todas as outras questões ambientais. O Norte, por exemplo, no que concerne à proteção de suas florestas temperadas, procura esquivar-se da aplicação de medidas equivalentes às que propõe para as florestas tropicais do Sul.

Todas essas características apresentadas por Conca sugerem que um estudo de caso da Amazônia - no caso deste trabalho, apenas da parte brasileira - é uma abordagem potencialmente privilegiada para a exploração do objeto aqui proposto - a dos efeitos das demandas ambientais emergentes sobre a noção de soberania.

\section{INTERVENÇÃO AMBIENTAL}

A expressão "intervenção internacional" pode ser entendida segundo diversos sentidos. Em um sentido mais restrito, pode significar a violação física das fronteiras nacionais de um Estado soberano com um propósito definido - por exemplo, o ataque a instalações militares ou o envio de ajuda humanitária a populações carentes. Em um sentido mais amplo pode-se pensar em um continuum que vá de uma situação limite, como acima, ao exercício da influência política, incluindo seus níveis mais brandos. Assim, o conceito de intervenção internacional pode abranger desde a intervenção militar propriamente dita até os polidos meios diplomáticos. E ainda, como já foi aqui apontado, a intervenção, enquanto contraponto da soberania, pode apresentar-se como força ou como direito.

Joseph S. Nye Jr. concebe a intervenção como força, e a entende como sendo uma escala de coerção, medindo a eficácia das ações externas em influenciar os assuntos internos de um Estado soberano ${ }^{72}$. Nos níveis mais baixos de coerção Nye coloca as tentativas de influência externa que deixam maior espaço para a tomada de decisões por parte desse Estado

${ }^{72}$ NYE, 1997, Cap. 6. 
soberano - discursos, veiculação de opiniões, ajuda econômica. À medida que vai aumentando o caráter coercitivo as atitudes externas vão deixando menos espaço para a livre tomada interna de decisões, e passam a expressar-se na forma de advertências militares, apoio à oposição política e bloqueio militar. Nos níveis mais altos de coerção, onde a tomada de decisões interna é mais fortemente restringida, a influência externa toma a forma de ação militar limitada ou, ainda, de invasão militar - em sentido restrito, uma intervenção internacional propriamente dita.

Parece ser nesse mesmo sentido de intervenção enquanto poder de coerção - em oposição a direito - que Le Prestre entende a politização da questão ambiental - a ecopolítica. O autor conclui que, na prática, o meio ambiente não é o objeto, e sim um mero instrumento das ações políticas ${ }^{73}$. Ecologia e política se fundem na ecopolítica pelo fato de ser papel da esfera política tomar as decisões que possibilitem à humanidade continuar a viver coletivamente. Nesse sentido tomar decisões políticas não significa necessariamente trilhar o caminho cientificamente mais adequado. A ciência ajuda a determinar o universo de opções disponíveis, mas a escolha de uma delas é uma questão de oportunidade e, muitas vezes, de acomodação de forças.

Conforme o Dicionário de Política a politização da questão ambiental se dá pela fusão de dois fatores: a irreversibilidade dos fenômenos e a diferenciação entre quem decide e quem é afetado pelas decisões ${ }^{74}$. Por irreversibilidade dos fenômenos se entende uma espécie de "ponto de não retorno", uma situação da qual é impossível sair simplesmente retrocedendo nos passos que levaram a ela. A diferenciação entre quem decide e quem é afetado pelas decisões faz com que essas decisões deixem de ser regidas por questões de ordem técnico-econômicas, e as transporta para a esfera da disputa de forças, ou seja, da política propriamente dita.

Também outros autores, colaboradores no já citado livro de Gene Lyons e Michael Mastanduno, parecem adequar- se a essa concepção de intervenção enquanto exercício da força, em oposição ao exercício de um direito superior. Jack Donnelly diz explicitamente que apenas em seu

\footnotetext{
${ }^{73}$ LE PRESTRE, 2000, Cap. 1 e "Conclusão".

${ }^{74}$ CONTI, 1986, p. 979-80.
}

sentido forte (coercivo) a intervenção afeta a soberania ${ }^{75}$. A intervenção internacional depende da aprovação da comunidade internacional. Ou esta a proíbe - e nesse caso a intervenção viola a soberania diretamente - ou a autoriza - situação em que a soberania é redefinida, ou seja, há transferência de autoridade do Estado para a comunidade internacional. Em ambos os casos trata-se do exercício da força, sobrepondo-se ou redefinindo o direito internacional.

A posição de James Rosenau também é clara76. Esse autor entende a soberania como um processo de vir-a-ser, equacionando a discussão na forma de um continuum entre soberania e não soberania onde esse segundo polo corresponde à intervenção. Nenhum desses extremos é (segundo a ética da convicção) moralmente superior ao outro, e os Estados atuais, em suas relações internacionais, devem ser ao mesmo tempo autônomos e interdependentes, o que não é de forma alguma contraditório. Analisando os diversos parâmetros e determinantes da ordem global, Rosenau verifica que a tensão entre soberania e intervenção é uma realidade, e que não tende necessariamente a se resolver. Toda a construção de Rosenau, ao menos implicitamente, sugere uma concepção de soberania enquanto poder de coerção.

É possível citar ainda Stephen Krasner, para quem toda intervenção é fruto de um interesse estatal externo ${ }^{77}$. Krasner admite que, dada a existência da intervenção, alguns Estados não são plenamente soberanos. Nesse sentido, admite que o liberalismo é muito melhor que o realismo para interpretar o fenômeno da intervenção. Mas, ao mesmo tempo, deixa claro que o que fere a soberania é a coerção externa interessada. Assim sendo, sugere o poder coercitivo estatal como uma chave de interpretação paradigmática da ordem internacional, até mesmo mais poderosa que o idealismo.

Mas o enfoque da intervenção enquanto força não é o único. É preciso tratar ainda da possibilidade da intervenção enquanto direito. Essa opção é particularmente clara em Bachelet ${ }^{78}$. Ainda que não defenda explicitamente a intervenção internacional, esse autor considera necessário que se abandone, ao menos em parte, a ortodoxia da soberania. No lugar da

\footnotetext{
${ }^{75}$ DONNELLY, in LYONS \& MASTANDUNO (eds.), 1995, Cap. 6.

${ }^{76}$ ROSENAU, in LYONS \& MASTANDUNO (eds.), 1995, Cap. 9.

${ }^{77}$ KRASNER, in LYONS \& MASTANDUNO (eds.), 1995, Cap. 10.

78 BACHELET, s.d., "Prolegómenos Ecológicos", Cap. 1 da Terceira Parte e Cap. 1 da Quarta Parte.
} 
soberania Bachelet propõe o princípio da ingerência, como seu polo oposto e complementar. A soberania estatal só é limitada por si mesma, e essa autolimitação dá origem ao direito e ao costume internacionais. Apenas na esfera do direito internacional, espaço onde a soberania limita a si própria, surge a possibilidade de ingerência. Tecnicamente, segundo Bachelet, a ingerência não tem como fonte a soberania voluntariamente diminuída, nem a ordem e o direito internacionais são criados de forma multilateral a partir de um comum acordo de vontade entre os Estados. Fundam-se, de fato, na opinião pública internacional. A ingerência aparece assim como uma necessidade de cooperação internacional, que ameaça a soberania não no sentido de destruí-la, mas de reordená-la face às novas exigências. De afirmada, a soberania tende a tornar-se negociada.

A ingerência seria no fundo um direito - o direito da humanidade à sobrevivência. Não é à toa que Bachelet propõe a necessidade de substituição das diversas soberanias estatais por uma única soberania do meio ambiente. Nesse sentido a ingerência nada mais é do que uma intervenção destinada a corrigir os efeitos perversos de um emprego abusivo da soberania estatal. Para tanto Bachelet prevê diversos tipos de ingerência, mas considera a ingerência ecológica como sendo a principal. Enquanto a ingerência humanitária beneficia as pessoas individualmente - e apenas algumas delas -, a ingerência ecológica se refere em última instância a todos os indivíduos, já que trata das condições de vida no planeta. Deve, também, beneficiar-se daquilo que foi recusado à ingerência humanitária: um sentimento de inegável urgência e necessidade. Bachelet acredita tão piamente na importância da ingerência ecológica que sugere que ela será num futuro próximo o novo elemento de articulação das relações internacionais.

Outro autor que segue a mesma linha de Bachelet, ao menos com relação à dimensão especificamente jurídica da intervenção, é Robert Jackson $^{79}$. Inserido na mais pura tradição cosmopolita kantiana, Jackson considera necessário diferenciar entre comunidade internacional e comunidade da humanidade. Pela primeira o autor entende o conjunto dos Estados soberanos; já a segunda engloba todo homem, independente de sua condição dentro de um Estado. Se, por um lado, considera- se que as relações internacionais tratam das relações entre Estados soberanos, o princípio da não intervenção permanece válido, como corolário do princípio

\footnotetext{
${ }^{79}$ JACKSON, in LYONS \& MASTANDUNO (eds.), 1995, Cap. 4.
}

da soberania estatal. Se, por outro lado, considera-se que as relações internacionais tratam das relações entre seres humanos, a não intervenção torna-se nociva, e é a ela que se torna necessário justificar. Atualmente os portadores de direitos e deveres na comunidade internacional são Estados e cidadãos, e não seres humanos, e por isso ainda há necessidade de justificar a intervenção. A questão central de Jackson é no fundo uma questão moral: trata-se de definir em quais situações é legal e legítimo intervir. $\mathrm{O}$ autor sugere que tais normas de justificativa podem estar passando por uma mudança, deixando de tratar da comunidade de Estados para tratar da comunidade de seres humanos, passando com isso a engajar-se mais na proteção dos direitos destes do que dos primeiros.

Essa suposta emergência dos direitos dos seres humanos, bem como a necessidade de justificar a não intervenção no caso de ameaça desses direitos, favoreceria diretamente o meio ambiente caso este fosse considerado parte dos direitos da humanidade. É justamente esse o posicionamento de Solange Silva-Sánchez ${ }^{80}$. Com a emergência do direito ambiental a autora identifica o surgimento de dois novos sujeitos de direitos: a natureza e as gerações futuras. Esses dois novos sujeitos exigem um novo tipo de cidadania, a cidadania coletiva. Diferente da cidadania tradicional, a cidadania coletiva atribui a seus sujeitos apenas direitos, e nenhum dever. Essa nova forma de cidadania, bem como os dois novos sujeitos de direitos, são fruto não apenas da ação estatal, mas também da mobilização da sociedade civil. Segundo a autora a construção de uma cidadania ambiental no Brasil faz parte de um processo mais amplo de reconstrução da sociedade civil. A política ambiental brasileira, que nasceu na década de 1930 e consolidou-se a partir dos anos 1960, sofre uma profunda reestruturação no decorrer da década de 1980. No início essa política foi implantada mais como resultado das ações de um Estado autoritário e centralizador. Em seguida foi subordinada aos imperativos da política econômica e da tecnocracia estatal. Por fim, sua consolidação teria sido o resultado da pressão direta de forças sociais organizadas. O movimento ambientalista teria finalmente logrado construir no Brasil o que Silva-Sánchez considera uma cidadania ambiental, ou o direito a um meio ambiente ecologicamente equilibrado.

\footnotetext{
${ }^{80}$ SILVA-SÁNCHEZ, 2000.
} 


\section{INGERÊNCIA ECOPOLÍTICA}

Norberto Bobbio considera os direitos do homem como necessários para a existência da democracia, e esta como sendo a única formação política onde existem as condições mínimas para a solução pacífica dos conflitos $^{81}$. Isso parece colocar o autor do lado da concepção jurídica de intervenção; mas seu pensamento é um pouco mais elaborado. Segundo Bobbio os direitos do homem - e portanto as possibilidades de democracia e de paz - surgem na transição da concepção organicista de sociedade para a concepção individualista. Da prioridade dos deveres dos súditos passa-se à prioridade dos direitos do cidadão. Emerge então um modo diferente de encarar a relação política, não mais ancorada no ponto de vista do soberano, e sim no do cidadão, em correspondência com a afirmação da teoria individualista da sociedade e em contraposição à concepção organicista tradicional. Os direitos nascem gradualmente, não todos de uma vez, nem de uma vez por todas. Surgem apenas com novos carecimentos, isto é, em função da mudança das condições sociais e quando o desenvolvimento técnico permite que sejam satisfeitos. Portanto os direitos do homem seriam históricos e relativos, e indicadores da evolução histórica.

Bobbio aponta uma recente multiplicação nos direitos do homem, de três modos. Primeiro, aumenta a quantidade de bens merecedores de tutela, isto é, que requerem intervenção direta do Estado. Segundo, a titularidade de alguns direitos típicos é estendida a sujeitos diversos do homem, como etnias, grupos, a humanidade como um todo, e até mesmo a ecologia. E terceiro, o homem passa a ser visto não mais de forma genérica e abstrata, e sim em suas diversas maneiras de ser em sociedade - é o surgimento dos direitos da mulher, da criança, do idoso, do doente, etc.

O importante em Bobbio é que a ideia de direitos humanos, bem como a de poder político advindo do povo, ou a de Estado de natureza, são construções conceituais datadas. Isso, conforme pretende-se aqui sugerir, serve como um ponto de reconciliação entre direito e força ou, mais especificamente, entre a intervenção vista como direito e a intervenção vista como coerção. Trata-se de um direito porque as condições sociais em mudança assim exigem (ou estão em vias de exigir), e ao mesmo tempo trata-se de força autorizada socialmente para garantir esses direitos. Tome-

\footnotetext{
${ }^{81}$ BOBBIO, 1992, primeira parte.
}

se por exemplo a questão ambiental. A partir do momento em que as condições sociais exigirem irrevogavelmente, e que o desenvolvimento técnico torne possível, passa a existir um direito próprio do meio ambiente. Tal direito, ainda que seja historicamente relativo, é historicamente reconhecido, e isso lhe possibilita contar com um poder de coerção legítimo. Assim direito sustenta coerção, e vice-versa. Direito e coerção tornam-se na intervenção internacional - e mais explicitamente na intervenção ambiental - as duas faces de uma mesma moeda, assim como na soberania estatal.

Andrew Hurrell parece dar razão à fusão entre direito e coerção aqui sugerida $^{82}$. Ele vê uma necessidade de reformar a ordem internacional interestatal, e de reformular os conceitos de soberania e de não intervenção. Hurrell encontra pouca vantagem ou viabilidade em um total abandono do sistema de Estados nacionais. Ao mesmo tempo, considera necessário dotar de dentes mais eficazes as normas da sociedade internacional. Sua sugestão vai no sentido de uma retração do critério tradicional de não intervenção, e da inclusão das preocupações humanitárias dentro do rol de pré-requisitos à paz e à segurança internacionais, permitindo com isso a ação dos organismos internacionais sobre os Estados.

Acompanhando os diversos autores apresentados até o momento, sugere-se aqui que as mudanças observáveis no cenário internacional levam a uma situação de limitação do princípio realista da não intervenção, e portanto a uma limitação relativa do conceito de soberania, acompanhados de um fortalecimento de direito e de fato das formas de organização interestatais coletivas. Se isso ainda não se verifica em todos os casos recentes, parece seguro apostar que é uma tendência para a qual as relações internacionais estariam rumando, e que tudo indica que venha a se tornar a regra.

Parafraseando Le Prestre, trata-se da transformação de estratégias nacionais em estratégias internacionais, ou seja, da transformação de uma estratégia fundada na maximização dos interesses individuais em uma maximização dos interesses coletivos ${ }^{83}$. Para lidar com essa nova situação Le Prestre considera adequado o conceito de regimes, que são instituições interestatais que diminuem a incerteza na cena internacional, e que portanto

\footnotetext{
${ }^{82}$ HURRELL, 1999.

${ }^{83}$ LE PRESTRE, 2000, Cap. 8.
} 
facilitam a busca do interesse coletivo. Para os fins deste trabalho um regime será considerado justamente como sendo um organismo ou um acordo interestatal coletivo, dotado de capacidade coercitiva e apoiado no direito. Por exemplo, um regime internacional do meio ambiente, que regule a conduta ambiental dos países e que regule a intervenção em caso de necessidade.

Outros autores parecem simpatizar com o conceito de regime, ainda que não o nomeiem explicitamente. Mesmo que não concordem diretamente com a definição de regime aqui adotada - que funde direito e coerção -, as propostas desses autores parecem sugerir que a realidade internacional ruma (ou deveria rumar) justamente no sentido aqui indicado. Ronnie Lipschutz e Ken Conca sugerem o conceito de interdependência ecológica global $^{84}$, onde mudança ambiental e resposta social seriam duas esferas entrelaçadas, gerando reciprocamente alterações uma na outra. Os autores apontam que essa dicotomia estaria ganhando espaço no debate sócio- político mundial, e que com isso a soberania nacional e a anarquia internacional não seriam simplesmente reproduzidas, mas também restruturadas de alguma forma. Jacqueline Switzer e Gary Bryner apostam em um ambientalismo cooperativo ${ }^{85}$, caracterizado por uma tentativa de busca de consenso entre as partes discordantes. Esse consenso não significa que todas as partes saiam satisfeitas do diálogo, mas garante que todas serão ouvidas e que todas as preocupações serão levadas em conta. O consenso é almejado, basicamente, em oposição ao uso arbitrário da violência. Gareth Porter, Janet Brown e Pamela Chasek acreditam que o aumento populacional, aliado à expansão mundial do consumo e ao espantoso desenvolvimento econômico, leva a importantes mudanças ambientais, o que faz surgirem políticas ambientais globais ${ }^{86}$. Para esses autores as questões ambientais globais não são determinadas de forma inequívoca pelo poder militar, mas dependem fundamentalmente da cooperação ativa de atores-chave; essa é a concepção que esses três autores têm de regime.

84 "Global ecological interdependence", livre-tradução; LIPSCHUTZ e CONCA, in LIPSCHUTZ \& CONCA (eds.), 1993, Cap. 1.

85 “Cooperative environmentalism", livre-tradução; SWITZER \& BRYNER, 1998, Cap. 12. 86 "Global environmental politics", livre-tradução; PORTER, BROWN \& CHASEK, 2000, Cap. 1.
Os diversos conceitos sugeridos por diversos autores interdependência ecológica global, ambientalismo cooperativo, políticas ambientais globais - apontam todos para o sentido aqui vislumbrado: uma reestruturação das soberanias estatais e um aumento da atividade da esfera internacional, e mais especificamente com relação às questões ambientais. Seria possível chamar todas essas propostas por um nome comum, e o primeiro que aparece histórica e logicamente é intervenção ambiental. Essa expressão no entanto já parece um tanto gasta, e precede toda a discussão desenvolvida neste capítulo. "Intervenção" é forte demais para significar uma atuação supranacional que conta com um direito, e "ambiental" parece um termo muito amplo, e portanto fraco demais, que não inclui a problemática do poder autorizado. Principalmente, "intervenção ambiental" não reflete a ideia de coletividade (ainda que interessada) ou de tutela autorizada; parece referir- se apenas a um abuso uni ou multilateral sobre as prerrogativas soberanas de um ou mais Estados. Sugere-se aqui, portanto, a utilização de uma outra expressão, ingerência ecopolítica, que reflete melhor a problemática à luz dos avanços propostos. Nesse sentido "ingerência ecopolítica" parece uma expressão mais precisa e mais avançada, que indica de forma mais fidedigna a criação consensual pelos Estados de uma tutela capaz de uma atuação ao mesmo tempo real e legítima do patrimônio ecológico mundial. É na direção de regimes de ingerência ecopolítica que o sistema internacional parece rumar, ao menos no que tange à questão ambiental.

O que se procurou fazer até aqui foi entender um pouco como se dá a alteração do conceito central de soberania frente às necessidades ambientais emergentes. Conca, por exemplo, enxerga ao mesmo tempo um enfraquecimento e um fortalecimento da soberania ${ }^{87}$. Ela se enfraquece no sentido de que é dito aos Estados o que fazer internamente. E ela se fortalece no sentido de colocar nas mãos do próprio Estado a defesa dos recursos ambientais em questão. Mas o importante não é distinguir entre o que é enfraquecimento e o que é fortalecimento da soberania. O importante é entender o que acontece com ela: uma reformulação, visando possibilitar uma tutela interestatal do meio ambiente.

Também não é central para este trabalho decidir em que medida essas mudanças são revolucionárias para o cenário internacional. Para Conca as

${ }^{87}$ CONCA, in LYONS \& MASTANDUNO (eds.), 1995, Cap. 7. 
mudanças geradas pela questão ambiental não implicam em alteração estrutural profunda nos pilares da política mundial (soberania, capitalismo e modernidade ${ }^{88}$. Para Dennis Pirages, por outro lado, a ecopolítica aparece como uma terceira revolução mundial, depois da revolução neolítica e da revolução industrial, postulando um novo paradigma global ${ }^{89}$. O importante, para os fins deste trabalho, é entender para onde leva essa mudança. O que a teoria sugere, como foi visto até aqui, é que a questão ambiental parece guiar as relações internacionais em direção a regimes internacionais de ingerência ecopolítica.

Mas tudo o que foi analisado até agora não passa de mera especulação teórica, e a teoria muitas vezes se descola do que ocorre na realidade e na prática. Para sanar essa lacuna pretende-se, a seguir, recorrer às evidências empíricas para verificar se estas corroboram ou desautorizam a hipótese aqui sugerida de uma tendência à construção de regimes internacionais de ingerência ecopolítica.

\section{AVALIAÇÃo CRÍTICA DA INGERÊNCIA ECOPOLÍTICA}

Os avanços científicos das últimas décadas têm deixado cada vez mais evidente o crescimento das perturbações ambientais, bem como a responsabilidade do homem sobre elas. $\mathrm{O}$ advento dos combustíveis fósseis como principal fonte de energia tem lançado na atmosfera quantidades imensas de gás carbônico, contribuindo para o aquecimento do planeta, o derretimento das calotas polares, o rareamento da camada de ozônio que protege a Terra dos raios ultravioleta, e mudanças climáticas tempestuosas como níveis recordes de calor e chuvas em excesso. As florestas, que auxiliam a diminuir o nível de gás carbônico livre na atmosfera, têm sido devastadas praticamente sem qualquer controle. Tal desmatamento também tem como consequência a destruição da biodiversidade, particularmente nas áreas tropicais. A crescente escassez de água potável, dados o crescimento populacional, o desenvolvimento industrial e a expansão da agricultura, tem deixado bilhões sem acesso ao abastecimento seguro e ao saneamento, resultando em milhões de mortes e facilitando enormemente a propagação de doenças. A degradação dos solos por erosão, salinização, avanço desregrado

\footnotetext{
${ }^{88}$ CONCA, in LIPSCHUTZ \& CONCA (eds.), 1993, Cap. 12.
}

${ }^{89}$ PIRAGES, 1978, Cap. 1. da agricultura em grande escala e sistemas de irrigação inadequados, contribui para a escassez de terras e ameaça a segurança alimentar da população mundial. A imensa produção diária de lixo, juntamente com o baixo índice de reciclagem, gera uma poluição crescente que prejudica cada vez mais a fauna, a flora, e o próprio ser humano. O crescimento desenfreado da população, acompanhado dos crescentes padrões de consumo e produção, faz apenas aumentar as quantidades de resíduos e substâncias tóxicas poluentes, com efeitos desastrosos sobre todo o meio. A crescente poluição e as fortes carências - de alimento, de ar limpo e de água - que sofrem os seres humanos, especialmente nos grandes centros urbanos, levam a fenômenos como a marginalização, a exclusão, a pobreza extrema e a deterioração da qualidade de vida da grande maioria da população mundial. Dificilmente alguém poderia dizer hoje em dia que o ambiente em que o homem vive - e que o próprio homem criou para si - é um ambiente saudável.

Medidas devem ser tomadas com urgência em defesa do meio ambiente. Nesse sentido o papel da Eco-92, ocorrida no Rio de Janeiro, é importante. Foi nessa megaconferência que surgiu a Agenda 21 com suas importantes propostas. Foi lá também que ficou clara a necessidade de conciliação internacional para que fosse possível levar adiante os esforços ecológicos. Porém, sob muitos aspectos, parece que as promessas feitas no Rio não encontraram solo fértil para germinar. Henrique Rattner, por exemplo, identifica desde então poucos avanços no âmbito das negociações internacionais ${ }^{90}$. Apesar dos esforços despendidos na década que se seguiu ao encontro, com inúmeras reuniões e debates sobre propostas, resoluções, metas e indicadores, o balanço geral não lhe parece animador. Esse autor alega que a resistência a normas internacionais mais rígidas, no plano das relações internacionais, se deve à protelação e recusa dos representantes dos governos dos países mais ricos, sobretudo os EUA, em assinar tratados e protocolos. Esses países alegariam, principalmente, que tais medidas ambientais poderiam gerar prejuízos para suas economias nacionais.

Rattner aponta que entre a Rio-92 e a Johanesburgo-2002 os países ricos retrocederam em diversos pontos antes acordados, apesar dos países pobres lhes chamarem a atenção para os efeitos altamente perniciosos e crescentes da degradação ambiental, bem como do alastramento da pobreza e da exclusão social. Com isso Rattner afirma que a década transcorrida

${ }^{90}$ RATTNER, 2002. 
entre as duas conferências foi totalmente perdida em tentativas de acordo, ou melhor, de restabelecimento dos patamares comuns de discussão estabelecidos pela primeira conferência. Pior do que essa perda de tempo precioso é o fato de tal consenso não ter sido atingido, recrudescendo a polarização entre Norte e Sul, e fazendo com que a conferência de Johanesburgo, ao invés de "Rio + 10", ficasse jocosamente conhecida como "Rio - 10". Por fim a tão esperada Eco-2002 começava sem ao menos um balanço inicial dos avanços - se é que houve algum - na implantação da Agenda 21. Enquanto isso aumentavam o consumo de desperdício e a devastação dos recursos naturais.

Christian G. Caubet sugere que, em se tratando das relações internacionais contemporâneas, haveria uma tendência concreta e hegemônica de exclusão dos fatores socioambientais das considerações que devem estruturar o intercâmbio comercial ${ }^{11}$. O comércio, segundo ele, seria capaz de pairar acima de considerações de quaisquer tipos, impondo sua lógica às demais. Esse tipo de raciocínio encontra adeptos até mesmo entre as organizações ambientalistas. Em nome da liberdade de comércio, que segundo o autor parece equivaler à liberdade de se obter lucros, chega-se ao limite de ignorar qualquer tipo de problema ou exigência resultante de imperativos coletivos. Trata-se de uma forte inversão de valores. Não é surpresa salientar, como o autor, que desde 1945 um aumento espantoso dos números relativos ao comércio correspondeu a um aumento da degradação das condições de vida da maioria da população da Terra.

Caubet chega a essas constatações após analisar a forma como se dão diversos tratados ambientais, e as relações entre estes e a "ideologia dominante" representada pelo sistema GATT/OMC. Como indício da validade de sua afirmação Caubet apresenta a mudança pela qual passa o antigo princípio do poluidor-pagador: se antes a ideia era de que cada Estado deveria pagar pela poluição que produzia, agora se cogita a possibilidade de exportação de direitos de poluição por parte dos países que poluem menos. Trata-se de otimizar economicamente os impactos das mais diversas formas de contaminação ambiental. Nas palavras do autor,

A obsessão do lucro é o parâmetro mais relevante das relações internacionais, quer na paz, quer na guerra. Não é, portanto, de se

\footnotetext{
${ }^{91}$ CAUBET, 2001.
}

estranhar muito que os setores da atividade econômica que menos se sujeitam a normas, sejam os das finanças e do comércio ${ }^{92}$.

Bill McKibben é defensor de uma postura ainda mais crítica, apontando os Estados Unidos como o grande vilão ambiental ${ }^{93}$. Segundo McKibben o efeito estufa traria com o tempo graves complicações a todas as partes do mundo, mas, no curto prazo, os Estados Unidos seriam mais afortunados do que qualquer outra região. Além de contarem com uma grande extensão territorial e de estarem situados em uma região de latitude média, os EUA encontram-se relativamente ilhados em termos de implicações ambientais. Por isso as consequências danosas do efeito estufa e do aquecimento global se fariam notar de forma mais vagarosa no território estadunidense. Talvez o país chegue, inicialmente e por um breve período de tempo, a colher benefícios quanto à produtividade de suas plantações. Isso, como aponta o autor, tem fortes implicações políticas.

O Protocolo de Quioto, por exemplo, única tentativa internacional para se chegar a um acordo sobre modestas reduções nos níveis de emissão dos gases estufa, tem encontrado inúmeros obstáculos, dentre os quais a notável recusa dos EUA em ratificá-lo. Ao contrário, ao invés de estabilizar as emissões desses gases, o país continua queimando cada vez mais combustíveis fósseis. Planos estadunidenses para economizar energia ou para se levar em conta diminuições "relativas" na liberação de gases estufa não passariam de medidas cosméticas. A verdade é que as necessidades energéticas dos Estados Unidos se elevariam em um terço até $2020^{94}$, e os planos do setor energético estadunidense não seriam outros a não ser explorar e queimar rapidamente todas as reservas de combustíveis fósseis disponíveis. Coincidência ou não, são inegáveis os benefícios que recentes guerras promovidas pelos EUA trazem às indústrias petrolíferas do país vide a Guerra do Golfo, que garantiu a liberdade comercial para as jazidas petrolíferas do Kuwait; a Guerra do Afeganistão, que possibilita uma rota alternativa para a exploração do petróleo do mar Cáspio; e a recente guerra com o Iraque, que abre para os EUA o acesso ao petróleo iraquiano.

Independente de quais sejam as classes de prerrogativas que guiem a ação interessada dos agentes, fica claro que elas muitas vezes se sobrepõem

\footnotetext{
${ }^{92}$ CAUBET, 2001, p. 169.

${ }^{93}$ McKIBBEN, 2001.
}

${ }^{94}$ McKIBBEN, 2001, p. 151. 
ao bem da coletividade. Seja por interesses econômicos, militares ou de qualquer outro tipo, os países parecem fortemente propensos a se afastar dos compromissos para com o meio ambiente, relegando aos outros os ônus de uma adequada gestão ambiental. Usando os exemplos acima, relativos ao comércio e aos Estados Unidos, este trabalho pretendeu deixar explícita a diversidade de alternativas que se colocam aos países, e o fato de que as escolhas destes nem sempre privilegiam o que é sugerido pelo bom senso. De certa forma isso já havia sido constatado quando ficou claro que a questão ambiental é no fundo política, e que por isso sua boa gestão depende sempre de uma gama de outros fatores que se colocam aos atores seus interesses, suas expectativas, as oportunidades sistêmicas, as atitudes das demais partes envolvidas, etc.

Essas constatações geram um forte ceticismo com relação ao sucesso dos regimes internacionais de ingerência ecopolítica. O problema é que tais regimes, ainda que apoiados em um direito e contando com uma capacidade de coerção, e ainda que acordados coletivamente, não são na prática garantidos por nenhuma instância supraestatal apoiada na legalidade ou na força. Em outras palavras, ainda que a teoria aponte para o surgimento de regimes coletivos de gestão do meio ambiente, tem-se observado que na prática os Estados preferem adotar a política do "cada um por si" - uma política que tem, na maioria das vezes, trazido crescentes prejuízos ao meio ambiente. $\mathrm{O}$ sistema internacional continua sendo anárquico, hierárquico e oligopolístico.

Em termos de intervenção internacional isso significa que os Estados tendem a intervir nos assuntos alheios quando querem - ou quando podem -, e não quando a intervenção é necessária ou bem-vinda. Do ponto de vista dos Estados interventores tudo vale para justificar a intromissão: desde a "necessidade moral" de se fazer algo por populações carentes, ao "dever acordado" de proteger a soberania dos Estados mais fracos. No fundo, justificar a intervenção perante a comunidade internacional pode não passar de mera formalidade, já que a justificativa mais forte, senão a única, costuma ser o interesse estatal.

Tendo visto como andam as questões da soberania e da intervenção nas relações internacionais contemporâneas, e tendo analisado como estas se relacionam com a questão ambiental, resta a este trabalho explorar a situação da Amazônia brasileira em meio a essa problemática, e tentar verificar a existência de uma posição do Brasil sobre a situação do ecossistema em vista.

\section{CAPÍtulo 3}

\section{A AMAZÔNIA BRASILEIRA}

\section{MAPEAMENTO DA AMAZÔNIA}

Por Amazônia entende-se aqui o vasto complexo de ecossistemas localizado na bacia hidrográfica do rio Amazonas, que tem uma superfície total de pouco mais de 7 milhões de $\mathrm{km}^{2}$ (ou seja, aproximadamente $40 \%$ do continente sul-americano). Estende-se por oito países: Brasil, Bolívia, Peru, Equador, Colômbia, Venezuela e, mais pela similaridade vegetal e climática do que pela unidade hidrográfica, Guiana e Suriname ${ }^{95}$. A cobertura vegetal predominante é a floresta, quente e úmida, e extremamente dependente das constantes chuvas que caracterizam a região. Apenas metade dessas chuvas se deve às correntes úmidas vindas do Atlântico; a outra metade seria o produto da evapotranspiração da própria floresta. A quantidade de água é tão grande que faz com que o rio Amazonas, com seus mais de mil afluentes, seja provavelmente o maior do mundo em volume de águas. Isso o torna potencialmente responsável por um quinto da água doce do planeta, além de possuir um imenso potencial hidroviário e hidrelétrico.

Ao contrário do que se pensou durante muito tempo, o solo da região é pouco fértil, sendo a maior parte (na área do Brasil, $83 \%$ ) $^{96}$ imprestável para o gado e para a lavoura. Com um solo fraco, o alimento das árvores vem da própria cobertura de folhas caídas. Mas o ponto forte da região, além das águas, é a biodiversidade, ou seja, a imensa diversidade de espécies animais e vegetais encontradas. A Amazônia é o último lugar do mundo onde novas espécies de mamíferos ainda são descobertas, e é o lar de 62 das 79 espécies de primatas do Brasil. As três mil espécies de peixes amazônicos perfazem 15 vezes a soma total de espécies dos rios europeus, e em uma área florestal equivalente a poucos quarteirões há mais espécies vegetais do que em toda a Europa. Na Amazônia há cerca de cinco mil espécies de árvores, enquanto

${ }^{95}$ MAZZEI, 1999. Segundo esses critérios a Guiana Francesa poderia ser incluída no rol dos "países amazônicos", o que nem sempre acontece na prática.

${ }^{96}$ LEITE, 2001, p. 58. 
em toda a América do Norte há apenas 650. A Amazônia colombiana, em especial, tem uma biodiversidade riquíssima, sendo o lar de cerca de $10 \%$ das espécies da fauna e da flora do planeta. Para que não restem dúvidas quanto à importância dessa biodiversidade, um quarto de todos os medicamentos modernos tem sua origem nas florestas tropicais.

Talvez seja conveniente, a esta altura, proceder um rápido apanhado contendo alguns dados sobre os países amazônicos, para que se possa em seguida abordar apenas a Amazônia brasileira.

A Amazônia boliviana corresponde a 11,2\% da bacia amazônica (cerca de 560 mil km²), e a $75 \%$ do território boliviano. Sua economia depende da extração de minérios e de gás natural, da exportação de produtos primários, e do plantio ilegal de coca. Os rios da Amazônia boliviana são facilmente navegáveis, mas tem faltado ao governo boliviano o capital necessário para priorizar uma infraestrutura viária e portuária adequada. Apenas recentemente a Bolívia tem pensado em uma "saída amazônica" como alternativa de escoamento para sua produção nacional.

A Amazônia colombiana representa 5,5\% da bacia (cerca de 250 mil $\mathrm{km}^{2}$ ), e $36 \%$ do país. Divide-se em duas porções bem distintas: a ocidental, de ocupação branca, e a oriental, de ocupação indígena. Foi alvo de diversos projetos malsucedidos de colonização, mas recentemente destacam-se os efeitos do garimpo, do plantio de coca e dos grupos guerrilheiros - é bem conhecida sua condição atual de guerra interna contra o narcotráfico, apoiada inclusive pelos Estados Unidos. Possui, na região amazônica, cidades de fronteira com o Brasil, que ajudam a contornar os obstáculos naturais para a interligação Brasil-Colômbia.

A região amazônica do Equador corresponde a apenas $1,7 \%$ da bacia amazônica (cerca de $80 \mathrm{mil} \mathrm{km} \mathrm{km}^{2}$ ), mas abrange $48,5 \%$ do país. Caracteriza-se principalmente pela falta de navegabilidade dos rios (dados os acentuados declives da região, resultado de sua proximidade com os Andes). Tentativas recentes de expansão da fronteira agrícola e de desenvolvimento industrial não têm tido bons resultados na região. Atua pouco para sua integração com os demais países amazônicos, pois lhe falta o capital necessário.

$\mathrm{Na}$ Guiana está presente menos de $0,1 \%$ da bacia amazônica (ou seja, menos de 5 mil $\mathrm{km}^{2}$ ), mas suas similitudes naturais, ecológicas e econômicas the garantem que $85 \%$ da superfície do país seja considerada região amazônica. Os principais problemas da região são o narcotráfico e as incursões de garimpeiros brasileiros. Suas fronteiras com o Brasil tendem a se tornar mais vivas com a construção de rodovias. Tal ligação é uma das prioridades do governo guiano.

A Amazônia peruana corresponde a $13 \%$ da bacia amazônica (por volta de $650 \mathrm{mil} \mathrm{km}^{2}$ ), e a $63 \%$ do território peruano. Pode ser dividida em selva alta (entre 400 e 2000 metros de altitude) e selva baixa (abaixo de 400 metros). Na primeira, localizada nos contrafortes andinos, predomina a agropecuária. Na segunda, nos vaus dos rios, predomina a atividade de extração, destacando-se o petróleo. Possui cidades fronteiriças com o Brasil, criando a possibilidade de uma ligação do Brasil ao oceano Pacífico - bem como do Peru ao Atlântico.

A bacia amazônica não alcança o território do Suriname, mas mesmo assim $91 \%$ do território desse país se encontra sob cobertura florestal considerada amazônica. A exploração de madeira e de ouro são as principais atividades econômicas da região. Pretende ligar seu território ao do Brasil o mais rápido possível, via Guiana ou via Guiana Francesa.

A Amazônia venezuelana corresponde a menos de $1 \%$ do total da bacia amazônica (isto é, menos de $50 \mathrm{mil} \mathrm{km}^{2}$ ), e corresponde a aproximadamente $20 \%$ de seu território. No que diz respeito a transportes, a região depende fundamentalmente do transporte aéreo, mas leva altamente em conta a possibilidade de contato rodoviário com o Brasil. A região possui recursos minerais praticamente intocados, e a fertilidade de seus solos é muito baixa.

$\mathrm{E}$, finalmente, é possível agora voltar os olhos para a parte brasileira da Amazônia. Totalizando quase 5 milhões de $\mathrm{km}^{2}$, representa $70 \%$ do total amazônico, e cerca de $60 \%$ do território nacional. É formada pela bacia sedimentar que acolhe a calha do rio Amazonas e seus afluentes, envolvida por elevações como o Planalto Central Brasileiro, o Planalto das Guianas, e os Andes. Dentre todos os países amazônicos o Brasil recebe duplo destaque: por possuir a maior parte da bacia amazônica, e por controlar a desembocadura desta no oceano Atlântico. Possui uma rede viária muito semelhante às de seus vizinhos, caracterizando-se por uma modesta $\mathrm{e}$ polarizada rede rodoviária, e uma imensa extensão navegável (mais de 27 mil km) ainda muito mal aproveitada. Essa região é campeã mundial em 
desmatamento e em queimadas, pois o povoamento e a colonização se dão sempre de modo predatório, seguindo o ritmo da expansão capitalista mundial. A região também é marcada por estratégias estatais com fortes impactos ambientais e sociais. A chamada "Amazônia Legal" brasileira é formada pela região Norte do Brasil, mais os estados de Mato Grosso, Tocantins e Maranhão. Dada a inadequação do solo para o gado e para a lavoura, não há dúvida de que sua vocação seja realmente florestal. Isso faz com que o manejo ou uso adequado do solo seja uma necessidade premente.

A ocupação brasileira da Amazônia remonta ao Tratado de Tordesilhas, um dos primeiros tratados de divisão das terras recémdescobertas a oeste no Atlântico Sul. Esse tratado reduzia o território brasileiro a talvez menos da metade do que é atualmente. Mas os limites costeiros do Brasil já eram então praticamente os mesmos de hoje em dia. Foi a partir dessa faixa costeira de concentração populacional que os portugueses montaram expedições para o interior do continente, conquistando mais tarde domínio legal sobre esse espaço. Repartindo linhas litorâneas sem o conhecimento prévio do terreno, o Tratado de Tordesilhas secionou geopoliticamente as duas grandes vias de penetração no continente sul-americano ${ }^{97}$. A foz do Prata ficou totalmente entregue aos espanhóis, proporcionando-lhes maiores oportunidades de expansão por aquelas terras - nos Pampas e no Chaco. A desembocadura do Amazonas, por outro lado, ficou nas mãos dos portugueses, que seguiram os afluentes do braço sul do rio - coincidentemente o melhor para a navegação - e se apossaram da maior parte da Planície Amazônica.

Em comparação com a América espanhola, a América portuguesa formou uma frente única e compacta, portanto mais propícia à penetração no terreno em profundidade. Isso porque Tordesilhas serviu menos como fronteira, e mais como o determinante de zonas de irradiação dentro de dois núcleos geohistóricos litorâneos - o português e o espanhol. Em outras palavras, a ocupação de um ponto da costa colocava o colonizador diante do desconhecido, do sem dono, do sem limite. Nesse sentido, segundo Therezinha de Castro $^{98}$, as fronteiras políticas entre as Américas espanhola e portuguesa só começaram a ser implantadas no século XVIII, através dos tratados de Utrecht (1713) e de Madrid (1750). Do ponto de vista

\footnotetext{
${ }^{97}$ CASTRO, 1986, p. 3.
}

${ }^{98}$ CASTRO, 1986, p. 7. português, surgem então os territórios decorrentes da exploração do Norte (Rio Negro, Piauí, Mato Grosso, Goiás) e da exploração platina (São Pedro, Santa Catarina, São Paulo).

A exploração e formação do território brasileiro deve muito a homens como Pascoal Moreira Cabral, Antônio Raposo Tavares e Pedro Teixeira. Raposo Tavares fez o primeiro circuito terrestre do Brasil, explorando a bacia do Prata e ligando-a à bacia do Amazonas. Pedro Teixeira, com sua Bandeira militar, integraria geopoliticamente a Amazônia ao Brasil. Pascoal Moreira Cabral instalou Cuiabá, na cabeceira do Prata, porém voltada para a Amazônia. Muito se deve, também, ao brasileiro Alexandre de Gusmão, ministro do rei de Portugal e autor do Tratado de Madrid de 1750. Nesse tratado Gusmão propõe o princípio do uti possidetis ${ }^{99}$, segundo o qual cada colônia - portuguesa e espanhola - devia continuar com o território que já ocupava. Por meio desse artifício, Gusmão garantia de direito aquilo que os bandeirantes já haviam conquistado de fato.

Pelo relevo mais alto e pela oposição espanhola que enfrentou no sul, o Brasil se afunilou no Prata, obtendo maior sucesso na exploração e ocupação da Amazônia. Ao se tornar independente, em 1822, os limites geohistóricos já davam ao Brasil uma forma geopolítica bem semelhante à atual. Desde então o Brasil apenas incorporou na Amazônia o território do Acre (1903), mas perdeu a província Cisplatina (em 1828), eliminando totalmente a presença portuguesa na foz do Prata. Por outro lado, na foz do Amazonas, o triunfo geopolítico foi pleno, com a eliminação das pretensões francesas na margem norte da desembocadura do rio.

Do ponto de vista das relações exteriores com respeito à Amazônia brasileira, o enfoque nacional parece ter mudado de maneira substancial desde a época da formação das fronteiras até o tempo presente. Não se pretende sugerir que a questão da segurança na região não seja mais uma prioridade. Mas, se antes ela recebia um enfoque negativo e até mesmo conflitivo, no último quartel do século XX passa a ser alvo de um enfoque mais positivo, onde as discussões giram em torno da cooperação - ao menos é isso o que sugere Pedro Motta Pinto Coelho ${ }^{100}$. Segundo esse autor, na busca de fórmulas diplomáticas factíveis para a região, os governos dos

\footnotetext{
${ }^{99}$ MATTOS, 1979 , p. 41.

${ }^{100}$ COELHO, 1992, p. 137.
} 
países amazônicos teriam, nas últimas décadas, demonstrado boa vontade e forte confiança recíproca. Houve nesse período um inegável aumento do diálogo político e econômico, e mesmo cultural, entre os países amazônicos. No entanto, a demonstração dessas vontades frequentemente esbarra em dificuldades nas condições de execução. Para que tais fórmulas encontrem condições de realização seria necessário identificar as tensões, equacioná-las e, na medida do possível, distribuí-las em módulos operacionais. De qualquer modo, a existência de bons relacionamentos parece possível, em uma modalidade até mesmo mais sólida, baseando-se no modelo da cooperação ao invés do conflito.

Os anos finais da década de 1970 testemunharam mudanças importantes no relacionamento entre os países amazônicos, talvez um reflexo das mudanças de valores vinculadas a um movimento sul-americano em direção à democracia. Na virada da década já era evidente o aumento dos encontros diplomáticos, até então raros no contexto amazônico. No início a aproximação se dava de modo bilateral. Em seguida seu caráter multilateral foi fortalecido, culminando, em 1978, com a celebração do TCA - Tratado de Cooperação Amazônica. No entanto o quadro de entendimento e cooperação desenhado teve sua progressão comprometida por fatores como a recessão latino-americana da década de 1980, a crise da dívida externa brasileira, e os anos de continuada dificuldade econômica pelos quais passaram os países da América Latina.

Em vigor a partir de 1980, o TCA pode ser visto como um marco do sucesso da cooperação e das boas relações entre os países da região amazônica. Integram o Tratado Brasil, Bolívia, Peru, Colômbia, Venezuela, Equador, Guiana e Suriname. No TCA estão firmados os princípios básicos para a cooperação regional, como a concepção de que para se alcançar o integral desenvolvimento dos respectivos territórios amazônicos é necessário manter o equilíbrio entre desenvolvimento econômico e proteção ao meio ambiente; ou, a ideia de que tanto o desenvolvimento socioeconômico quanto a preservação do meio ambiente são responsabilidades inerentes à soberania de cada Estado. Na análise desses dois princípios fica evidente a contradição entre as prerrogativas da soberania nacional e as diretrizes internacionais acordadas. No entanto o TCA tem a capacidade de não apenas prever essa tensão, mas também de tentar equacioná-la, por meio da recomendação de que sua estrutura seja considerada como sendo um acordo-quadro flexível, capaz assim de nortear matrizes coerentes para o desenvolvimento da cooperação regional. Segundo observou o embaixador Rubens Ricupero, o TCA seria regido por cinco princípios gerais:

a) a competência exclusiva dos países da região no desenvolvimento e proteção da Amazônia (o Tratado não é aberto a adesões);

b) a soberania nacional na utilização e preservação dos recursos naturais;

c) a cooperação regional como meio de facilitar a realização dos dois objetivos anteriores;

d) o equilíbrio e a harmonia entre a proteção ecológica e o desenvolvimento econômico; e) a absoluta igualdade entre as partes $^{101}$.

Dessa forma o TCA parece driblar o embate entre soberania e determinação supraestatal, não encarando diretamente o problema, mas sugerindo uma saída tangencial. Mas o que Pedro M. P. Coelho considera mais significativo a respeito do TCA é sua ênfase nos assuntos indígenas e, sobretudo, no tema do meio ambiente.

Embora às vezes pareça exaltar por demais uma importância com a qual o TCA de fato não conte, Pedro M. P. Coelho é engenhoso ao sugerir o Tratado como um marco genérico, que lança as condições para uma aplicação específica dos conceitos contemporâneos de cooperação em áreas fronteiriças. Seria uma espécie de ponte para um novo paradigma no qual as regiões fronteiriças passam a receber um influxo valorativo maior.

Mas a Amazônia não possui apenas fronteiras externas. Constitui, sob certos aspectos, uma fronteira interna, para o Brasil e para o mundo. É, por exemplo, uma fronteira de recursos, com espaços inexplorados pelo homem. Sua população é de apenas cerca de dez milhões de habitantes ${ }^{102}$. Seja do ponto de vista da agricultura, da pecuária, da extração madeireira ou mineral, da biodiversidade ou da ocupação populacional, grande parte do território amazônico constitui um espaço ainda a ser desbravado. A Amazônia é um dos últimos grandes espaços não apropriados do globo.

${ }^{101}$ COELHO, 1992, p. 116, nota de rodapé.

102 Em 1991, segundo o IPAM (Instituto de Pesquisa Ambiental da Amazônia); citado in LEITE, 2001, p. 19. 
Apenas do ponto de vista nacional, mais da metade do território brasileiro não está ainda economicamente incorporado ao sistema espacial. Bertha Becker aponta o fato de que durante décadas houve planos governamentais para a ocupação do espaço amazônico; mas ao mesmo tempo critica tais planos como mal planejados e/ou mal executados ${ }^{103}$. A estratégia do governo de implementação de centros na periferia amazônica não implica necessariamente em desenvolvimento global da região. Pelo contrário, torna-se para a autora cada vez mais evidente que os desequilíbrios sociais persistem. É fato constatado que a Amazônia passou a estabelecer fluxos com o centro nacional - a região sudeste - mas o desenvolvimento não chega à periferia, pois a dependência continua e até se reforça. Se por um lado diminui a dependência externa, por outro lado aumenta a dependência interna com relação ao sudeste, e o caso é que a Amazônia continua periférica. Para Becker um desenvolvimento racional para a Amazônia, geopoliticamente falando, implica dois elementos. Primeiro, uma exploração de caráter conservacionista, que mantenha o equilíbrio ecológico. Em segundo lugar, um crescimento autossustentado, que requer povoamento permanente e real integração à economia nacional.

Tal como ocorre atualmente, a ocupação amazônica leva a diversos tipos de conflitos reais, como por exemplo os conflitos étnicos e fundiários. Os conflitos étnicos ocorrem quando territórios tradicionais indígenas encontram-se de alguma forma ameaçados. Tais territórios podem já estar demarcados - isto é, reconhecidos legalmente - ou em processo de demarcação, que pode levar anos. Em geral a ameaça que se coloca é alguma forma de ocupação econômica - garimpo, madeireiras, etc. - que invadem os territórios indígenas já demarcados ou não. Mas às vezes são as próprias modalidades de demarcação exercidas pelo governo quem atua contra os interesses indígenas. A demarcação, além de não raro levar um tempo imenso, às vezes não se conclui de modo favorável para os habitantes tradicionais. E, quando os favorece, nem sempre é efetivamente respeitada. A presença de povos indígenas na Amazônia - e, principalmente, deixar para eles a responsabilidade sobre esse território geralmente não é vista com bons olhos pelos militares, receosos de abrir mão de suas prerrogativas sobre as fronteiras nacionais.

\footnotetext{
${ }^{103}$ BECKER, 1982.
}

Outro tipo de conflito interno que ocorre na Amazônia brasileira é o conflito fundiário. Essa é a principal preocupação de Bertha Becker em seu livro Geopolítica da Amazônia ${ }^{104}$. Segundo a autora, a principal característica da Amazônia enquanto fronteira de recursos - principalmente agrícola - é a forma de ocupação que depreda o solo. Junto (ou mesmo antes) das estradas planejadas aparecem os primeiros ocupantes do terreno: proprietários, grileiros, posseiros, arrendadores e arrendatários. A ocupação se dá de uma forma tal que impossibilite aos trabalhadores (isto é, aos imigrantes que passam a habitar o local) a posse do solo e o acesso aos meios de produção. Uma forte mobilidade social da população é garantida pela propriedade privada da terra, que leva sempre à abertura de novas fronteiras com mão de obra mais barata e terra mais produtiva. A mão de obra se desloca para onde quer o capital, em busca de emprego e de uma utópica estabilidade. E assim opera esse duplo mecanismo de monopólio privado da terra e mobilidade da força de trabalho. Segundo Becker esse mecanismo seria uma estratégia estatal para manter o latifúndio exportador de recursos, esboçada nos anos 1960 e cristalizada nos anos 1970 por meio de projetos de integração nacional como a Polamazônia ${ }^{105}$. Através de políticas coerentes com essa estratégia global o Estado regula ao mesmo tempo o monopólio da propriedade da terra e a mobilidade da força de trabalho. Trata-se, portanto, da valorização diferenciada de parcelas do espaço e de populações.

Por fim, tocando em um ponto de interesse direto para este trabalho, existe o conflito ecológico, entre preservação e devastação do meio ambiente. Neli Aparecida de Mello tem algo a dizer sobre esse aspecto ${ }^{106}$. De acordo com ela, se até os anos 1970 o foco de estudos da região se concentrava sobre os conflitos sociais, a partir dos anos 1990 os impactos ambientais deixam seu papel secundário e tomam a cena nas negociações entre os atores amazônicos.

Para essa autora o final da década de 1980 é marcado por inúmeras políticas brasileiras que agravam o desmatamento: incentivos fiscais para investimentos (especialmente agropecuários) na região; crédito subsidiado e garantia de preços para a agropecuária; programas de desenvolvimento e

\footnotetext{
${ }^{104}$ BECKER, 1982.

${ }^{105}$ BECKER, 1982, p. 218.

${ }^{106}$ MELLO, 2002
} 
infraestrutura regionais (rodovias, hidrelétricas, indústrias, mineração com dinheiro público); colonização, assentamentos e regularização fundiária; política fiscal econômica; regulação do setor minerador ${ }^{107}$. No contexto internacional o Brasil era considerado um dos grandes contribuintes para o agravamento dos problemas globais e detentor de uma política de meio ambiente pouco expressiva. É numa conjuntura com essas características, e de preparação para a Eco-92, que surge o PPG-7 - Programa Piloto de Proteção das Florestas Tropicais Brasileiras. Esse programa, resultado de um consórcio entre o governo brasileiro e o Banco Mundial, teve certamente como seu maior resultado a reconfiguração das forças geopolíticas no território amazônico, ao fomentar as ligações global-local, chamando a atenção para a importância do aprendizado ambiental, e ao difundir princípios, técnicas, alternativas de sistemas produtivos e desfazendo estereótipos técnicos e políticos. A implementação do PPG-7 foi bastante difícil, pois desde o início o governo brasileiro e o Banco Mundial tinham visões antagônicas quanto aos problemas ambientais. Para o primeiro, ainda que não se pudesse negar os problemas, o saldo era positivo, ou seja, as políticas governamentais estariam bem adequadas às estatísticas de desmatamento amazônico. Já para o segundo esse saldo era negativo, e o destaque caía sobre os problemas ambientais gerados pelo desmatamento da Amazônia brasileira.

No final da década de 1990 surge a necessidade de uma revitalização do PPG-7, e aparece então a proposta de que seja feito um zoneamento ecológico-econômico da região amazônica. O objetivo de tal zoneamento seria equacionar de maneira apropriada as diferentes problemáticas amazônicas dentro do contexto espacial, incorporando tanto as dimensões sociais quanto as dimensões ambientais desses problemas. Mas o próprio zoneamento, por si só, constituía um problema a parte, tanto com relação à escala quanto à metodologia a serem utilizadas. Especialmente quanto à escala, não havia qualquer fio condutor que agregasse os interesses estaduais ao interesse federal e ao interesse internacional; assim, jamais se chegou realmente a um consenso quanto ao tamanho das unidades de zoneamento - se estas deveriam se dar no nível municipal, estadual, macrorregional, etc.

\footnotetext{
${ }^{107}$ MELLO, 2002, pp. 184-5.
}

A autora parece concluir a certa altura que não há um modelo de desenvolvimento sustentável para a Amazônia, porque isso pressupõe a superação de "paradoxos conceituais e políticos", ou seja, a coexistência de interesses diversos ${ }^{108}$. A autora constata, como grande desenvolvimento da discussão ambiental dos anos 1990, o surgimento do econegócio, com a premissa de que o meio ambiente, em seus elementos biológicos e vegetais, constitui uma nova fonte de recursos a ser explorado ${ }^{109}$. A essa concepção seria possível acrescentar a politização da questão ambiental, sua transformação em objeto de barganha do jogo de poder nacional e internacional. Dessa forma o conflito ecológico não é apenas um problema interno da Amazônia brasileira, e sim um fator de preocupação internacional. A dimensão ambiental é uma nova exigência global, que exige novos modelos de tomada de decisão local. O conflito ecológico se caracteriza, portanto, por uma discussão mais ampla, entre interesses privados e interesses locais e internacionais, entre a lógica liberal e a lógica de conservação, entre o desenvolvimento econômico e o desenvolvimento sustentável.

\section{NOVOS E VELHOS ATORES AMAZÔNICOS}

Até aqui foram observadas algumas das principais políticas governamentais referentes à Amazônia, e os problemas e contradições dessas políticas entre si. Foram citadas iniciativas multilaterais como o TCA; estratégias de colonização que reproduzem o subdesenvolvimento como a Polamazônia; iniciativas governamentais que agravam o desmatamento; a dificuldade de ações concretas como no caso do PPG-7 e do zoneamento ecológico-econômico. Esse investimento governamental na Amazônia brasileira não só não teria gerado desenvolvimento na medida esperada, como teria aberto espaço para uma ocupação predatória que causa imensos danos ecológicos. Mas a atuação do Estado brasileiro na Amazônia não se faz apenas através do governo. Militares e diplomatas também são, ao lado do governo propriamente dito, atores estatais, e como tais detêm sua parcela de responsabilidade na ocupação da região.

Os militares recebem destaque quando se trata da geopolítica da Amazônia. Isso ocorre porque os primeiros estudos geopolíticos no Brasil

${ }^{108}$ MELLO, 2002, p. 314

${ }^{109}$ MELLO, 2002, p. 325 
não se deram em um ambiente acadêmico, mas sim militar. A geopolítica brasileira não teria sido, como na Europa, um desenvolvimento da geografia política local. Seria, antes disso, uma cópia do modelo pronto europeu. Nesse ambiente as adaptações europeias eram algumas vezes mal feitas e não condiziam com a realidade nacional, mas foram elas que de uma forma ou de outra guiaram a ocupação do espaço amazônico ${ }^{110}$. Dentro desse pensamento geopolítico militar é possível citar como pensadores mais influentes, tanto na teoria quanto na execução dos projetos, autores como Mario Travassos, Golbery do Couto e Silva, e Carlos de Meira Mattos. É o pensamento desses autores que será, a seguir, sinteticamente analisado.

Inicialmente faz sentido começar pelo pioneiro, Mario Travassos ${ }^{111}$. Travassos via as relações geopolíticas da América do Sul em termos de dois antagonismos dominantes. $\mathrm{O}$ primeiro era $\mathrm{o}$ antagonismo Atlântico/Pacífico, que dividia as costas sul-americanas; o segundo, o antagonismo Amazonas/Prata, que dividia o escoamento das águas da vertente atlântica do continente em duas desembocaduras distintas. Com relação ao primeiro antagonismo Travassos sugere como autoevidente a separação das duas vertentes, a atlântica e a pacífica, pela Cordilheira dos Andes. Ainda assim, examinando-se a Cordilheira em grandes linhas, percebe-se a existência de algumas "vias de transfusão" onde ambas as vertentes se encontram. Tratam-se dos pasos e dos nudos; os primeiros, passagens naturais de uma para outra vertente, e os segundos, centros comuns de dispersão de águas ${ }^{112}$. Quanto aos nudos, o autor diz ocuparem notáveis posições no anfiteatro amazônico, e que ainda teriam a revelar um fantástico papel funcional.

Quanto ao segundo antagonismo, que divide a vertente atlântica em duas bacias hidrográficas distintas, Travassos vê em ambas ótimos escoadouros para o Atlântico. Sob esse aspecto a bacia amazônica levaria uma vantagem geográfica com relação à do Prata, por situar-se mais próxima dos polos consumidores do hemisfério norte. Entretanto, fatidicamente, a foz do Prata estaria levando uma vantagem circunstancial sobre a foz amazônica, pelo fato de contar com uma rede ferroviária (ligando Buenos Aires a La Paz) que atrairia para o Prata o escoamento do

\footnotetext{
${ }^{110}$ COSTA, 1990, pp. 239-41

111 TRAVASSOS, 1935
}

112 TRAVASSOS, 1935, pp. 53-4. interior do continente sul-americano. Como solução e alternativa para essa situação desvantajosa para o Brasil, Travassos sugere a ferrovia MadeiraMamoré, e em seguida o transporte fluvial, para atrair para a bacia amazônica o fluxo das exportações continentais.

\section{Mapa $\mathbf{I}^{113}$}

(Mario Travassos)

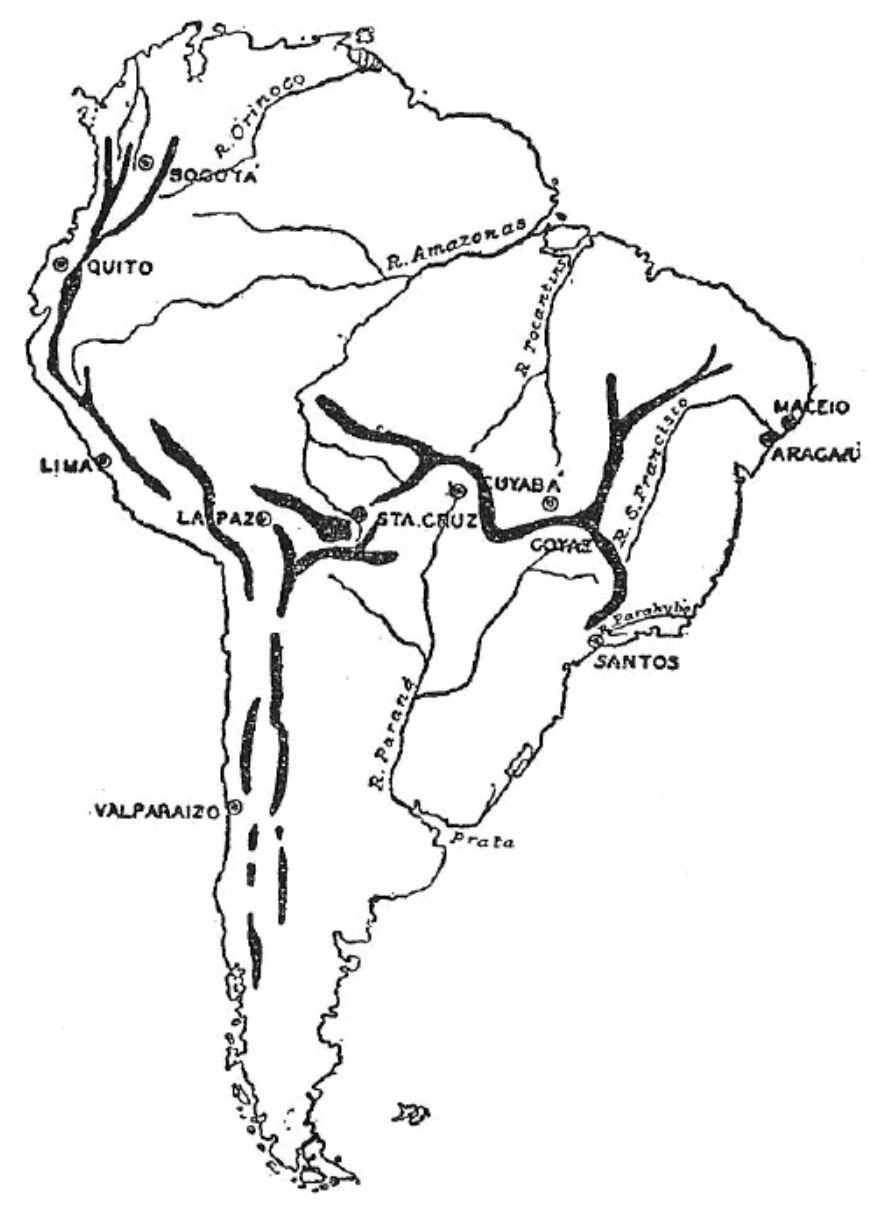

${ }^{113}$ In TRAVASSOS, 1935, p. 21 
Golbery do Couto e Silva, talvez o mais célebre desses autores, prima por sua vez pela geopolítica interna. Visa a incorporação efetiva e a vitalização de todo o amplo domínio brasileiro. Entre seus objetivos nacionais permanentes coloca

(...) a salvaguarda intransigente de nossa independência política, admitidas, embora, autolimitações, nunca essenciais, da soberania nacional, em benefício da cooperação e da paz internacionais $(. . .)^{114}$

Sua visão do território nacional é a de que há um núcleo central de desenvolvimento (a região sudeste), três "penínsulas" onde o desenvolvimento estaria presente em menor escala (as regiões sul, centrooeste e nordeste), e uma imensa região ilhada das demais, à qual o desenvolvimento não atingia (a região amazônica). Sua estratégia de integração para o vasto território nacional consistia no fortalecimento dos laços (ou melhor, das condições viárias gerais) entre o núcleo e as penínsulas, e então partir para a incorporação da "ilha" amazônica. Essa incorporação se daria segundo dois caminhos: a utilização da região centro-oeste como base avançada, e o aproveitamento do eixo navegável do rio Amazonas.

Unindo as três áreas ecumênicas atlânticas ao centro e à Amazônia, Golbery esperava criar as condições de circulação que possibilitassem a integração e o desenvolvimento do território nacional como um todo. Assim fortaleceria o país em sua totalidade, livrando-o da contingência de depender quase que exclusivamente dos transportes marítimos periféricos para as comunicações entre seus focos de civilização.

Carlos de Meira Mattos também demonstra grande preocupação pela geopolítica interna nacional ${ }^{115}$. Analisa as concepções do Brasil como país de vocação continental, e as concepções do Brasil como país de vocação fundamentalmente marítima, e concilia ambas em um meio termo. Ao mesmo tempo em que é verdade que o Brasil possui duas vezes mais fronteiras terrestres do que litorâneas ${ }^{116}$ - o que lhe conferiria uma vocação continental -, também é verdade que o país tem seus núcleos históricos de povoamento e desenvolvimento voltados para o Atlântico - o que revelaria

\section{${ }^{114}$ SILVA, 1967, p. 74.}

115 MATTOS, 1979, e MATTOS, 1980

${ }^{116}$ Os números são da ordem de 16 milhões de km de fronteiras terrestres, contra 8,5 milhões de $\mathrm{km}$ de fronteiras marítimas. uma vocação marítima. Meira Mattos consegue equilibrar as duas posições, sugerindo que ambas são verdadeiras: a primeira devendo-se a fatores estruturais, e a segunda a fatores contingenciais. Mas, considerando que a maritimidade brasileira já tem sido extensamente explorada desde os primeiros tempos da colonização, o autor sugere a continentalidade como o novo campo a ser explorado e desenvolvido, reservando-lhe um futuro papel como fonte de poder nacional.

\section{Mapa II ${ }^{17}$}

(Golbery do Couto e Silva)

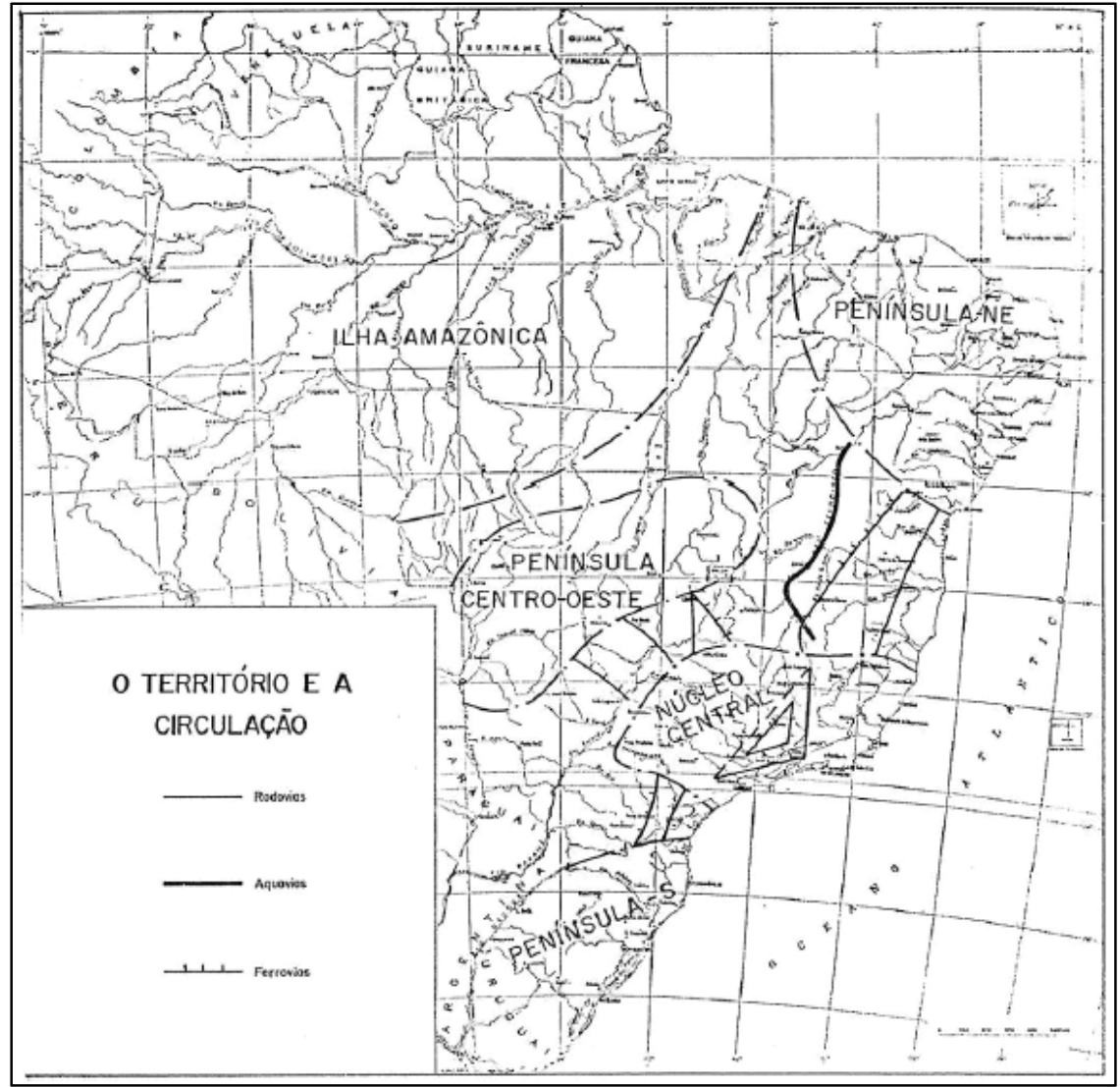

${ }^{117}$ In GOLBERY, 1967, p. 44. 
O grande espaço interno que Meira Mattos vê como sendo necessário integrar e fortalecer é justamente a região amazônica. Quanto a isto, enquanto analista atento que é, esse autor não se preocupa apenas com a parte brasileira da Amazônia. Entende, sim, que para se obter sucesso na ocupação e desenvolvimento da região, é necessário levá-la em conta em sua totalidade, pensando sempre no conjunto das diversas Amazônias nacionais. O desenvolvimento da Amazônia seria, portanto, um projeto comum a todos os países amazônicos. E assim o autor sugere o conceito de Pan- Amazônia. Rubens Ricupero, falando sobre o Tratado de Cooperação Amazônica, chega a sugerir que

(...) a regionalização ou vocação regional da Amazônia é o melhor antídoto para coibir o aparecimento de modernas reencarnações da desmoralizada mas persistente manobra da internacionalização. ${ }^{118}$

Meira Mattos aponta que desde o período colonial o Brasil busca transformar a Amazônia em um espaço econômico. Essas tentativas, no entanto, ficaram sempre limitadas às proximidades dos eixos do grande rio e seus afluentes. Apenas no governo Médici, com o Programa de Integração Nacional, é que se começou a abrir espaço para o desenvolvimento da viação amazônica, mais especificamente com a criação de rodovias. $O$ presidente Geisel, em 1975, daria continuidade a esse empenho por meio de seu projeto Polamazônia. Entretanto nenhum desses projetos chegou a ser concluído, assim como muitos outros depois deles.

São três as frentes possíveis de abordagem à Pan- Amazônia, conforme Meira Mattos ${ }^{119}$. A primeira e mais evidente é pela desembocadura do Amazonas, subindo pelo leito desse rio e de seus numerosos afluentes. Essa é a estratégia adotada desde o século XVII, com a fundação de Belém no lado sul da desembocadura. A segunda estratégia é descer para a Planície Amazônica a partir do Planalto Central Brasileiro. Foi justamente essa ideia que comandou os planos de desenvolvimento da Amazônia a partir dos anos 1960 - os planos de Médici e Geisel de interligar as hidrovias da região, e de conectá-las ao restante do país por meio de rodovias. A Transamazônica, uma espécie de marginal sul do rio Amazonas, também teria essa função. A terceira frente, ainda pouquíssimo

\footnotetext{
${ }^{118}$ MATTOS, 1980, pp. 122-3.

${ }^{119}$ MATTOS, 1979, pp. 71 e ss., e MATTOS, 1980, pp. 152-5.
}

desenvolvida, seria a chamada frente fronteiriça, ou seja, o arco que vai de Roraima a Rondônia, e que engloba todos os afluentes da margem norte do Amazonas e parte dos afluentes da margem sul. Essa frente envolve as fronteiras brasileiras com a Guiana, Venezuela, Colômbia, Peru e norte da Bolívia, e é fundamental para o desenvolvimento conjunto de uma PanAmazônia que possui um altíssimo nível de continentalidade.

Nessa frente não existe um sistema pronto de estradas - a Perimetral Norte serviria como um primeiro esboço de conexão viária -, o que faz com que seja necessário utilizar os cursos navegáveis como o principal meio de articulação. A frente também não conta imediatamente com centros ecumenizadores, sendo necessário criá-los para atrair o desenvolvimento a essas áreas fronteiriças. Assim Meira Mattos propõe a criação de centros ou polos internacionais nessas regiões de fronteira, articulando a Amazônia e portanto a América do Sul. O autor sugere como candidatos três polos principais: o primeiro centrado em Boa Vista (Roraima), ligando-se a Manaus, à República da Guiana e à Venezuela; o segundo, entre Brasil, Peru e Colômbia, teria lugar às margens do rio Solimões, onde a via fluvial se apoiaria nas pequenas cidades da região fronteiriça para ligar Manaus a Iquitos, no Peru; o terceiro polo internacional seria estabelecido em torno de Porto Velho (Rondônia) e Rio Branco (Acre), articulando-se com Cuiabá e Manaus e com a Bolívia.

É inegável a atualidade dessas propostas militares. A Amazônia é um tema que vem recebendo atenção crescente nos últimos anos, especialmente, como foi visto, diante das novas preocupações ambientais emergentes. As principais vias de acesso e os núcleos de integração do espaço amazônico continuam os mesmos, ou ao menos servem como parâmetro para novos estudos mais adequados às necessidades sócio ecológicas. As visões geopolíticas dos militares, se perdem um pouco de seu vigor frente às novas preocupações locais e internacionais, continuam extremamente válidas para explicitar as diretrizes segundo as quais se deu a ocupação e a irrigação viária da região nas últimas décadas.

Quanto aos atores diplomáticos, pouca evidência foi encontrada sobre suas diretrizes visando a ocupação da Amazônia. Não que a região amazônica não seja uma preocupação dos diplomatas, mas, ao menos no material a que este trabalho teve acesso, parece que essas preocupações ficam em grande parte limitadas ao nível do discurso. Talvez seja possível 
generalizar as preocupações nesse nível usando os termos de Geraldo Quintão, enquanto Ministro de Estado da Defesa. Quintão aponta a diplomacia como esfera de resolução de conflitos na região, substituindo mas não descartando - a atuação das Forças Armadas ${ }^{120}$.

\section{Mapa III ${ }^{121}$}

(Carlos de Meira Mattos)

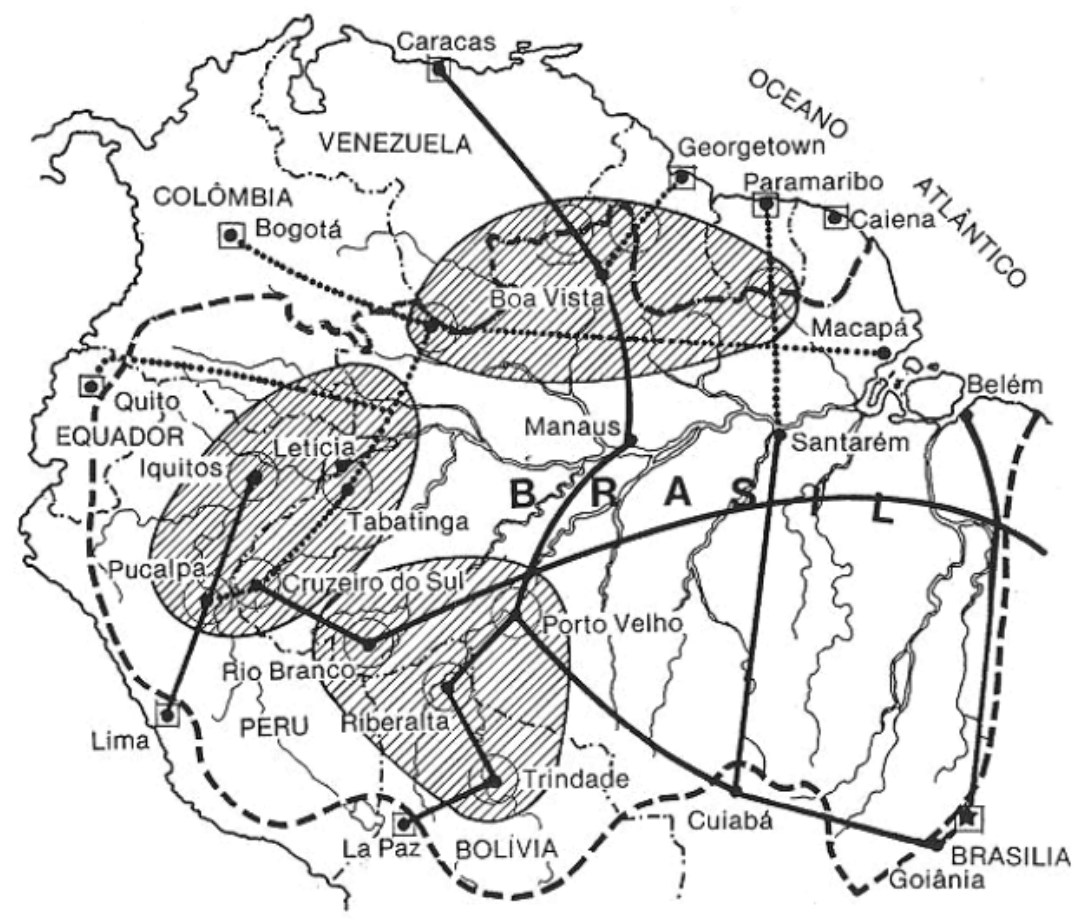

Desse modo parecem ser poucas, ou quase nulas, as intervenções diplomáticas, no plano da ação prática, sobre a Amazônia brasileira. Portanto parece que a atuação dos atores estatais na região amazônica fica, em geral, submetida aos interesses econômicos (que teriam guiado as políticas governamentais), e geopolíticos ${ }^{122}$.

\footnotetext{
${ }^{120}$ QUINTÃO, 2000.

${ }^{121}$ In MATTOS, 1980, p. 168.

${ }^{122}$ COSTA, 1988 , p. 65
}

No plano da geopolítica, é o intento deste capítulo ressaltar a possibilidade de uma ruptura do pensamento geopolítico militar com respeito à Amazônia, e a substituição deste por uma geopolítica mais "civil" "23, ou seja, que leva mais em conta os atores societários. O final da geopolítica militar pode ser atribuído a Geraldo L. Cavagnari Filho, que, em meados dos anos 1980, rejeita explicitamente o discurso triunfalista do "Brasil Potência", ressaltando que no fundo o País era sujeito às determinações estratégicas dos Estados Unidos e não tinha consciência de sua verdadeira posição na divisão internacional do trabalho. $\mathrm{O}$ surgimento da nova geopolítica ocorreria, quase que ao mesmo tempo que a derrocada da antiga, com Bertha Becker, em um verdadeiro processo de resgate civil. Seguindo o modelo francês de renovação da Geografia, Becker praticamente instaura um novo campo de estudo, com uma legítima vocação acadêmica interdisciplinar e incorporando ao debate as reivindicações locais frente às demandas internacionais.

Esse movimento de ampliação da esfera civil não se limita à geopolítica amazônica. Novos atores parecem surgir e substituir os atores tradicionais (estatais) em diversos níveis, destacando-se o nível da sociedade e o nível econômico. No nível societário é possível apontar o notável fortalecimento de diversos atores civis, como sindicatos, associações, universidades e organizações não governamentais. Todos esses atores passam a colaborar com uma parcela de responsabilidade sobre a Amazônia, e todos são ouvidos, em maior ou menor grau, na formulação de políticas para a região.

Dentre os atores societários, os de maior destaque são provavelmente as ONG's. Pouco material sistematizado foi encontrado a seu respeito, por isso este trabalho optou por operar principalmente com o material produzido pelas próprias organizações. Elas surgem decididamente como uma nova categoria de atores, fruto da descentralização estatal, preenchendo o vácuo de poder resultante da retomada dos rumos da nação por parte das forças civis. As ONG's são representantes da sociedade civil em todos os níveis desta, pois atuam com base local e com vínculos globais. Isso lhes garante a capacidade de representar outros atores societais, como os sindicatos e as associações. Mais recentemente as ONG's têm diversificado sua atuação, trabalhando não mais apenas com denúncias e

${ }^{123}$ COSTA, 1990, Cap. V.2 
levantamento de dados, mas também com proposição de modelos e, no caso das ONG's ambientais, até mesmo com econegócios. Especificamente no caso ambiental, ONG's como o Imazon, WWF, Greenpeace e tantas outras têm se mostrado legítimas defensoras das intenções verdes do planeta e da sociedade civil.

Além das organizações não governamentais, outro ator societário que não pode ser deixado de lado é a universidade. $O$ meio acadêmico tem recentemente contribuído significativamente para o desenvolvimento de pesquisas sobre a Amazônia brasileira. Se essas pesquisas têm se dado muito mais no âmbito da técnica do que da filosofia, parece ser apenas uma questão de tempo e de incentivos adequados para que um certo equilíbrio seja atingido. Esforços nesse sentido não faltam. É o caso, por exemplo, de Bertha Becker, autora analisada anteriormente neste trabalho, e de Wanderley Messias da Costa, geógrafo da USP, especialista em Amazônia.

Ao lado dos atores societários, há ainda como expressão dos novos atores na região os atores econômicos. É claro que tais atores já estavam presentes na Amazônia no período anterior, mas encontravam-se fortemente constringidos pelas políticas dos atores estatais, estes sim dominantes. Juntamente com o advento da sociedade civil, os atores econômicos passam a contar com uma autonomia maior na região amazônica. Os atores econômicos podem ser subdivididos em nacionais e internacionais. Os nacionais parecem, como sugere Becker, preocupados principalmente com a expansão da fronteira interna de recursos, influenciando, na medida do possível, as políticas governamentais. Ainda assim, sua atuação é fortemente dependente das políticas estatais. Quanto aos atores econômicos internacionais, estes dificilmente podem ser entendidos como elementos de peso nas políticas brasileiras sobre a Amazônia. Isso acontece porque praticamente não há capital estrangeiro atuando autonomamente na região, ou seja, toda a participação econômica estrangeira encontra-se regulamentada por normas e parcerias impostas pelo governo brasileiro.

Material pronto e sistematizado sobre os atores econômicos é um tanto escasso, e mais uma vez a opção seria trabalhar com material bruto, isto é, com dados quantitativos vagamente interpretados. Ainda assim arrisca-se aqui insinuar, com base no material encontrado, que os atores econômicos ocupam na região amazônica uma posição subordinada à dos atores societais. Os primeiros parecem ainda confinados, nos tempos atuais, a procurar espaço de atuação nas brechas deixadas pelas iniciativas governamentais presentes, estas fortemente influenciadas pela sociedade civil. Para todos os efeitos, este trabalho sugere que os atores societários (ONG's e sociedade civil) é que devem ser tomados como mais significativos com relação à Amazônia na época atual.

O objetivo não é eleger, dentre todos os atores disponíveis, os únicos que devam ser levados em conta, ou que devam ser considerados "paradigmáticos". Tal artifício seria por demais restritivo e dotado de uma significativa falta de visão. O que se pretende fazer é apenas elencar os atores mais atuantes em determinado período, que por seus méritos próprios e pelo contexto específico de cada caso lograram se destacar dos demais atores, deixando-os à sua sombra. É o caso dos atores (estatais) militares antes da década de 1980, e dos atores societários (especialmente as ONG's) no período posterior.

Parece possível, desse modo, propor os atores societários (em especial as ONG's) e os militares como representantes, respectivamente, de novos e de antigos temas - no primeiro caso o meio ambiente, e no segundo a soberania. Esse é um critério que, se por um lado não representa uma conclusão acabada, por outro lado não pode deixar de ser levado em conta em futuras elucubrações a respeito da problemática do meio ambiente no que diz respeito à soberania dos Estados.

Mas outro ponto que se deve salientar é o fato de que, enquanto seguiu as diretrizes formuladas pelos autores geopolíticos tradicionais (Travassos, Silva e Meira Mattos), o Brasil possuía uma política consistente de defesa da soberania nacional, o que não se pode afirmar com certeza para o período posterior (da abertura democrática e do advento dos novos temas e novos atores). No primeiro período os atores principais eram os militares, e sua posição era clara. Já no segundo período os atores principais passam a ser as organizações não governamentais e, apesar dos laços de interesses comuns que as ligam, não é possível dizer que proponham uma diretriz ou modelo acabado para a conduta nacional como um todo. Antes dos anos 1980 a soberania nacional brasileira - no que diz respeito à Amazônia - era objeto de uma política nítida e consistente. A partir de então se torna um campo de dúvidas. As certezas vão se dissipando conforme mudam os protagonistas. 
Os militares parecem, assim, os primeiros e únicos atores a formular uma estratégia global para a ocupação da Amazônia. Mas, apesar da atualidade que as propostas militares conservam, há que se levar em conta os novos atores - especialmente a sociedade civil - e as novas demandas ambientais. Uma das grandes apostas desses novos atores e demandas é o econegócio. Trata-se de uma tentativa de conciliar exploração e preservação dos recursos ambientais, como no caso dos "produtos verdes", isto é, produtos ecologicamente responsáveis. O econegócio é, no fundo, a mais nova face do desenvolvimento sustentável, buscando uma exploração consciente dos ecossistemas em todos os seus recursos - hídricos, farmacêuticos, minerais, etc. A grande questão com a qual se defronta a presente investigação é: em que medida o econegócio gera condições para a ocupação da Amazônia? Parece ainda cedo demais para dar uma resposta a essa indagação, pois as primeiras modalidades de econegócio apenas começam a se esboçar, e além disso o econegócio ainda tem que vencer a competição contra a exploração predatória. Ao invés de fazer suposições infundadas, parece mais adequado a este trabalho limitar-se a sugerir a ocupação da Amazônia como uma preocupação que deve estar sempre presente para os formuladores de políticas brasileiros - sejam eles os velhos atores estatais, sejam os novos atores sócio- econômicos. Em todo caso, quanto a esses últimos, parece que a ocupação territorial ainda não faz parte de suas prioridades.

\section{CONSIDERAÇÕES FINAIS}

Durante cerca de meio século o cenário das relações internacionais foi tomado por uma divisão do mundo decorrente da Guerra Fria. Dois grandes blocos, liderados respectivamente pelos Estados Unidos e pela União Soviética, davam ao mundo uma característica de conflito entre Leste e Oeste que tendia a se sobrepor às demais questões. De um lado os EUA comandavam a OTAN, aliança atlântico-ocidental. De outro lado a URSS dirigia o Pacto de Varsóvia, articulação dos países socialistas lesteeuropeus. Tal divisão de mundo se mantinha em uma espécie de equilíbrio de terror onde cada avanço de um dos lados recebia como resposta certa um avanço correspondente do bloco oposto. Do duelo desses dois titãs tentava ficar de fora, mal e sofregamente, um terceiro partido ou "terceiro mundo", neutralista, constituído pelas nações geralmente pobres e subdesenvolvidas do hemisfério Sul. As questões desses últimos tornavam-se secundárias frente ao persistente duelo entre os blocos ocidental e soviético.

Com o final da Guerra Fria e o fim da bipolarização militar e ideológica, abre-se espaço para a discussão de temas antes relegados ao segundo plano. Dentre eles, ressurge o tema da soberania. Não que a questão não estivesse presente durante o período que então se findava; mas estava presente de uma forma "congelada", paralisada, como tudo mais, pela divisão do mundo entre liberalismo e socialismo. Até a queda do Muro de Berlim e a fragmentação da União Soviética, importava pouco o grau em que determinado Estado conseguia manter-se realmente autônomo. $\mathrm{O}$ mais importante era o lado em que ele figurava no conflito universalizante - ou se pretendia para si uma condição de neutralidade. Mas, a partir da década de 1990, voltou a fazer sentido questionar se um Estado é ou não soberano.

A questão da soberania ressurge num contexto onde se busca entender o que acontece atualmente na esfera internacional. O paradigma de bipolaridade que era válido durante a Guerra Fria perdeu sua validade, mas não se sabe com precisão o que se tem em seu lugar. As principais apostas vão no sentido de uma unipolaridade abrangente por parte da superpotência vencedora (como quer Francis Fukuyama), ou no sentido de uma "unimultipolaridade" cultural (na verdade civilizacional, segundo Samuel Huntington). Acontecimentos que tiveram lugar nos últimos anos, como os 
atentados de 11 de setembro de 2001 e a decorrente guerra dos Estados Unidos contra o terror - efetivada em ataques contra o Afeganistão e o Iraque - sugerem uma relativização ou mesmo exclusão de fóruns multilaterais como a ONU, e o fortalecimento de políticas unilaterais por parte dos EUA. A nova doutrina unilateral estadunidense de guerra preventiva contra o terror talvez seja elucidativa do cenário que se descortina nas relações internacionais para os próximos anos. Mas talvez o cenário internacional ainda esteja em um período de transição, que ainda não encontrou seu novo paradigma. Para resolver essa questão é necessário saber que instituições atualmente detêm poder sobre os destinos dos atores internacionais. Para entender as relações internacionais contemporâneas é preciso saber o que foi feito da soberania estatal.

Parece claro que a soberania tal como concebida no sentido clássico, isto é, como campo onde o Estado exerce efetivamente seu direito e sua força, vem sendo ameaçada e mesmo atacada. Não é demais recordar, o conceito de soberania com o qual este trabalho opera é definido internamente pela inexistência de um poder que se iguale ao estatal, e externamente pelo não reconhecimento de um poder superior ao do Estado. Mas atualmente surgem concepções como as de soberania limitada ou soberania compartilhada, tentando-se adequar o conteúdo tradicional do conceito às novas formas das relações internacionais. A grande dúvida parece ser se a soberania continua sendo um conceito fundamental para o entendimento das relações entre os Estados contemporâneos, ou se é apenas uma reminiscência de um conceito que já foi um dia mais sólido. Este trabalho aponta no sentido de que, mesmo não sendo mais exatamente adequada à realidade internacional, a ideia de soberania ainda não pode ser descartada. O termo aparece o tempo todo nos discursos nacionais, e países agressores se veem invariavelmente constrangidos a se reportar aos "direitos soberanos" dos países agredidos. É o caso, por exemplo, da recente incursão americana e inglesa no Iraque, que apesar da falta de cerimônia em derrubar o regime vigente e reorganizar o Estado, preocupouse o tempo todo em garantir que o povo iraquiano teria assegurada sua soberania sobre o país e sobre seu petróleo. Fenômenos desse tipo ocorrem ainda, tendo já passado mais de uma década desde o final da Guerra Fria. Se por um lado parece evidente que a soberania não está se firmando como o novo paradigma das Relações Internacionais, por outro lado parece inegável que ela ainda não foi totalmente rejeitada, e talvez tenha ainda uma longa participação no drama internacional.

Uma outra face da soberania, como já foi discutido, é a intervenção internacional. Apesar de boa parte deste trabalho se dedicar a questões internas da Amazônia brasileira, o fundo que percorre essas questões é a preocupação com modalidades hipotéticas de intervenção externa. Aqui a definição de intervenção internacional depende do que exatamente se entende por soberania. No caso deste trabalho, adotar a concepção clássica de soberania como parâmetro implica em considerar intervenção internacional qualquer tipo de interferência na esfera interna de decisões de determinado Estado. Trata-se de uma gama bastante ampla de ações, que pode ir desde invasões militares a pressões diplomáticas, mas essa amplitude não afeta a operacionalidade do conceito. Apenas é o caso de se pensar a questão como uma escala de coação a coerção, que vai aumentando na medida em que se amplia a capacidade de influência externa sobre as condições internas de tomada autônoma de decisões.

A atual preocupação com a intervenção internacional deriva do surgimento dos "novos temas" nas relações internacionais. No pós-Guerra Fria surge espaço para que se discutam temas como o meio ambiente, os direitos humanos, a segurança global e o narcotráfico, entre outros. Mais do que isso, o fim da bipolarização Leste-Oeste abre espaço para que esses temas sejam discutidos por uma ampla variedade de atores, e para que surjam os mais diferenciados pontos de vista. Quanto aos atores atuais, há tanto os estatais - os Estados propriamente ditos - quanto os não estatais transnacionais, como as ONG's, e multinacionais, como determinadas empresas. Quanto aos pontos de vista, pode-se elencar pelo menos dois: o dos governantes ou do Estado, e o dos governados ou da sociedade. De forma concomitante a essa abertura, e vindo a confirmá-la, verifica-se também o crescente papel da sociedade nas questões interestatais. As organizações não governamentais vêm crescendo bastante em número, em qualidade de trabalho e em capacidade de atuação, tanto dentro de um único país quanto na esfera internacional. É o caso, por exemplo, do Greenpeace, do Instituto Socioambiental, e do WWF.

Este trabalho delimitou seu escopo de preocupação com a intervenção internacional à esfera da questão ambiental. Apesar das singularidades desta questão, acredita-se aqui que ela pode ser tomada 
como representativa das demais. As questões humanitária e de segurança global, por exemplo, ocupam-se mais diretamente e com maior propriedade da vida humana, mas a questão ecológica a trata de um ponto de vista mais amplo e mais filosófico, além de mais abstrato. Isso talvez torne mais fácil entender o papel da intervenção - e por tabela da soberania - de um ponto de vista mais cosmológico, na "grande ordem geral das coisas".

Os temas da ingerência ecológica são tanto amplos quanto específicos. São amplos no sentido de dizerem respeito ao mundo como um todo e serem portanto de responsabilidade coletiva. Por exemplo, quando se trata de questões supranacionais, como a escassez de água limpa e o efeito estufa; ou ainda quando os efeitos da poluição de um Estado afetam outros Estados. Mas também são temas específicos por tratarem de problemas localizados, como a devastação das florestas tropicais, que se encontram (ainda que às vezes precariamente) demarcadas dentro de determinado Estado em particular, e portanto, ao menos teoricamente, submetidas à soberania deste.

Em meio a essa enormidade de problemas levantados a questão central que este trabalho procurou explorar é na verdade bem definida. Trata-se de tentar entender um pouco melhor o posicionamento brasileiro com relação à soberania nacional na Amazônia. "Posicionamento brasileiro", vale lembrar, é aqui entendido como uma consistência geral das posições defendidas e das atitudes adotadas pelo País, seja uma consistência geral dessas posições entre si, ou delas com relação a determinados fins, meios ou valores. Trata-se, antes de tudo, de uma construção conceitual que facilita que se opere teoricamente para a consecução dos objetivos aqui buscados. "Posicionamento brasileiro" constitui, por si só, uma categoria complexa. Inicialmente porque seria necessário identificar quem fala em nome do Brasil em uma situação como essa. Um sem-número de atores se propõe à tarefa. Em primeiro lugar há os militares, responsáveis por excelência pela defesa da pátria, e portanto diretamente interessados na soberania sobre a Amazônia. Como foi visto, os militares tiveram enorme influência nas políticas para a região até meados da década de 1980, tanto em sua formulação quanto em sua implementação. Pode-se até mesmo dizer que a colonização do território amazônico - senão do Brasil como um todo -, mesmo em sua faceta de políticas governamentais, seguiu sempre os imperativos militares (como a transferência da "capital amazônica" de São
Luís para Belém, e mais tarde para Manaus). Os militares são os responsáveis diretos pela unidade territorial que se manteve na América portuguesa, em oposição à fragmentação ocorrida na América espanhola. Veja-se, por exemplo, os esforços do Duque de Caxias pela manutenção da unidade nacional.

Mas os militares não são os únicos preocupados em falar em nome do Brasil. Os diplomatas também têm essa preocupação. O corpo diplomático, de forma complementar aos militares, representa a voz e os gestos de um país no exterior. Esse corpo deve ser entendido de uma forma abrangente, composta não apenas por diplomatas de carreira, mas também por delegados, ministros, membros do Poder Executivo, ou qualquer outro agente credenciado pelos governantes a representar o governo brasileiro junto a outros países e instituições internacionais, e em seu nome firmar acordos e assumir compromissos. Diplomatas também tiveram papéis importantes na configuração territorial do Brasil, como o caso de Alexandre de Gusmão, que no século XVIII firmou o Tratado de Madrid. A relação entre militares e diplomatas é complexa e entrelaçada, e uma análise dessa relação não cabe dentro do escopo deste trabalho. $O$ fato é que ambos se pretendem representativos da coletividade que é o Estado. Pela dificuldade de se encontrar material da diplomacia brasileira a respeito da Amazônia, este trabalho se inclina a acreditar, até encontrar evidências em contrário, que o corpo diplomático brasileiro nutre, em geral, um solene desinteresse pela região amazônica na maior parte de seus aspectos.

Além desses dois atores é possível citar a produção do meio acadêmico como representativa dos interesses de um país. Esta nem sempre está de acordo com militares ou com diplomatas, constituindo às vezes um verdadeiro núcleo de resistência. Mas no caso em questão - soberania na Amazônia - nota-se que historicamente os militares formaram e guiaram, durante longo tempo, a produção acadêmica brasileira - como foi visto, no Capítulo 3, a partir dos exemplos de Mario Travassos, Carlos de Meira Mattos e Golbery do Couto e Silva. Uma certa independência parece estar nascendo recentemente, com obras de um cunho geopolítico mais moderno como os trabalhos de Bertha Becker e de Wanderley Messias da Costa. Mesmo assim, parece que tais obras ainda têm um longo caminho a percorrer até serem realmente reconhecidas e de fato implementadas pelos 
formuladores de políticas nacionais. Sua possível condição de inspiradora do "posicionamento brasileiro" parece, portanto, bastante frágil.

Como último advento dessa série de atores, juntamente com o pensamento acadêmico crítico, é possível citar a sociedade civil. Entende-se aqui por sociedade civil um conjunto de atores não estatais organizados com uma finalidade específica. Com atos, propostas e ações, a sociedade civil brasileira vem ganhando espaço, desde a década de 1980, no debate entre as propostas de ocupação da região amazônica. A atuação de ONG's, associações de moradores, habitantes da região, sindicatos e demais interessados tem se provado eficiente em muitos casos, e tem muitas vezes conseguido conciliar desenvolvimento material com exploração de recursos naturais. Uma figura que alcançou repercussão internacional foi Chico Mendes, que defendeu os direitos das populações e dos trabalhadores amazônicos até ser morto pelos interesses de particulares a quem incomodava. Também merece destaque o trabalho que as igrejas católicas e evangélicas vêm realizando junto às populações locais. Esse tipo de trabalho indubitavelmente favorece a formação de núcleos de sociedade civil mobilizada e atuante. Desse modo a sociedade civil é um ator que de fato não pode ser ignorado, e que é apontado por muitos como a solução para a ocupação responsável da Amazônia brasileira.

Como balanço geral do que até agora foi dito, parece que atores mais recentes (como a sociedade civil) estão, ao menos em parte, substituindo os atores tradicionais (diplomatas e militares) no que diz respeito à tomada de posição com relação à soberania na Amazônia. Isso não quer dizer, de forma alguma, que os militares não influenciem mais as políticas ocupacionais e de monitoramento do território, e nem que essas políticas tenham sido deixadas inteiramente à mercê de modalidades civis de autogestão. Também não se pretende afirmar que diplomatas e acadêmicos estejam inteiramente descartados, até porque a inserção desses na problemática amazônica parece ser por demais recente e ainda muito rarefeita para ser analisada dentro dos limites deste trabalho.

A relação entre militares e sociedade civil no contexto de atuação na Amazônia parece mais uma complementação do que uma substituição no sentido absoluto do termo. Ambos os atores são interlocutores legítimos, e o fato de agirem segundo padrões de atuação diferenciados não significa que sejam excludentes entre si, ou que apenas um deles deva ser levado em consideração. Parece se tratar, até onde este trabalho pode verificar, de uma complementação saudável de funções que, se bem coordenada, pode render bons frutos à preservação e ao desenvolvimento amazônico. Essa mudança de centralidade dos atores, dos militares para a sociedade civil, pode ser somente um reflexo do processo de democratização do país. Mas, por outro lado, também pode estar intrinsecamente ligada ao papel do povo na soberania nacional. O que se pretende sugerir é que a tal substituição dos militares pela sociedade civil remete diretamente a Hermann Heller, o autor segundo o qual o próprio povo é o detentor do poder soberano. Parece inegável que, em um país democrático, ainda que os militares conservem suas características próprias de atuação na Amazônia, estes devem estar sempre submetidos à esfera civil. Se cabe aqui fazer uma sugestão aos teóricos da soberania, esta sugestão seria no sentido de que seja feita uma releitura de Heller, já que esse autor parece deter uma certa atualidade, mas que ao mesmo tempo precisa ser reinterpretado à medida que a soberania estatal clássica vacila nos dias atuais. Talvez alguma pista para essa reinterpretação seja encontrada justamente nos autores que tratam do tema dos regimes internacionais (como Philippe Le Prestre), por darem um tom mais atual ao debate da autonomia estatal.

Voltando à questão do "posicionamento brasileiro", não se espera que qualquer um desses atores (governo, militares, diplomatas, acadêmicos, sociedade civil) elucide de uma vez por todas quem é que fala pelo Brasil. Eleger um deles como representante seria fácil, porém denotaria falta de atenção para com os meandros da realidade empírica. Seria um artifício por demais simplificador, e induziria ao erro dada sua unidimensionalidade. $\mathrm{O}$ que se pretendeu fazer aqui, ao invés disso, foi indicar quais atores parecem mais significativos, em determinados períodos, para o "posicionamento brasileiro". Além disso a própria ideia de posicionamento é de difícil manejo. É complicado pegar dezenas de posturas diferentes dentro do âmbito de determinado ator e dizer que se trata de um posicionamento unívoco desse ator como um todo. E também, o fato de um ator se posicionar de determinada forma em nada garante que os demais o aceitem como representante legítimo de toda a nação, e nem que os demais Estados o aceitarão como representante legítimo daquele Estado. Daí a necessidade de um mapeamento amplo, procurando incluir todos os interlocutores legítimos. Pois não há apenas um representante do Estado, mas sim diversos 
interlocutores, sem que apenas um deles monopolize o discurso e as atitudes estatais.

Espera-se que esse breve conjunto de observações tenha contribuído para um melhor entendimento da questão da soberania estatal frente ao tema emergente do meio ambiente. Mais especificamente, espera-se ter caminhado no sentido de um entendimento preliminar, um reconhecimento das percepções brasileiras sobre a soberania na Amazônia. O entendimento de tais percepções parece fundamental para se pensar a hipótese de uma intervenção estrangeira na Amazônia brasileira. A constatação da alteração nos principais atores da região, partindo dos militares e chegando a uma complementação destes pela sociedade civil, parece especialmente relevante, e merece ser aprofundada e levada em conta em futuros trabalhos sobre a região.

\section{BIBLIOGRAFIA CITADA}

BACHELET, Michel, s.d.: Ingerência Ecológica - Direito Ambiental em Questão, Instituto Piaget, Lisboa [original de 1995].

BECKER, Bertha K., 1982: Geopolítica da Amazônia, Zahar Editores, Rio de Janeiro.

BOBBIO, Norberto \& BOVERO, Michelangelo, 1987: Sociedade e estado na filosofia política moderna, segunda edição, Brasiliense, São Paulo.

BOBBIO, Norberto, 1992: A Era dos Direitos, Campus, Rio de Janeiro [original de 1990; ensaios de 1964-90].

BOBBIO, Norberto, 1995: "Estado, Poder e Governo", in Estado, Governo e Sociedade, Paz e Terra, São Paulo/Rio de Janeiro [original de 1985].

BODENHEIMER, Edgar, 1946: Teoria del Derecho, 2a. edición española, Fondo de Cultura Economica, México [original de 1940].

BODIN, Jean, 1992: Los seis libros de la república, 2a. edición, Colección Clásicos del Pensamiento, Tecnos, Madrid [original de 1576].

CASTRO, Therezinha de, 1986: Retrato do Brasil - atlas-texto de Geopolítica, Biblioteca do Exército Editora, Rio de Janeiro.

CAUBET, Christian Guy, 2001: "O comércio acima de tudo (e o meio ambiente fora da lei)", in Revista Lua Nova, no. 52.

COELHO, Pedro Motta Pinto, 1992: Fronteiras na Amazônia: um espaço integrado, FUNAG/IPRI, Brasília.

CONTI, Laura, 1986: verbete "Política e Ecologia", in Norberto BOBBIO, Nicola MATTEUCCI \& Gianfranco PASQUINO: Dicionário de Política, UnB, Brasília [original de 1983].

COSTA, Wanderley Messias da, 1988: O Estado e as Políticas Territoriais no Brasil, Editora Contexto/EDUSP, São Paulo. 
COSTA, Wanderley Messias da, 1990: Geografia Política e Geopolítica, tese de doutoramento, Departamento de Geografia da Faculdade de Filosofia, Letras e Ciências Humanas da Universidade de São Paulo.

HELLER, Hermann, 1995: La soberanía - contribución a la teoría del derecho estatal y del derecho internacional, 2a. edición, UNAM y FCE, Santiago de Chile [original de 1927].

HINSLEY, F. H., 1972: El concepto de soberanía, Editorial Labor S. A., Barcelona [original de 1966].

HOBBES de Malmesbury, Thomas, 1979: Leviatã ou Matéria, forma e poder de um estado eclesiástico e civil, 2a. edição, Coleção Os Pensadores, Abril Cultural, São Paulo [original de 1651].

HURRELL, Andrew, 1999: "Sociedade Internacional e Governança Global”, Revista Lua Nova, no. 46.

KELSEN, Hans, 2000: Teoria Geral do Direito e do Estado, 3a. edição, Martins Fontes, São Paulo [original de 1945, publicado em 1961].

KRASNER, Stephen D., 1999: Sovereignty - Organized Hypocrisy, Princeton U. P., Princeton.

LASKI, Harold J., 1937: Studies in the problem of sovereignty, USA [original de 1917].

LE PRESTRE, Philippe, 2000: Ecopolitica Internacional, SENAC, São Paulo [original de 1997].

LEITE, Marcelo, 2001: A Floresta Amazônica, Col. Folha Explica, Publifolha, São Paulo.

LIPSCHUTZ, Ronnie D. \& CONCA, Ken (eds.), 1993: The State and Social Power in Global Environmental Politics, Columbia U. P., New York.

LYONS, Gene M. \& MASTANDUNO, Michael (eds.), 1995: Beyond Westphalia? State Sovereignty and International Intervention, John Hopkins U. P., Baltimore and London.

MATTEUCCI, Nicola, 1986: verbete "Soberania", in Norberto BOBBIO, Nicola MATTEUCCI \& Gianfranco PASQUINO: Dicionário de Política, UnB, Brasília [original de 1983].
MATTOS, Carlos de Meira, 1979: Brasil - Geopolítica e Destino, Livraria José Olympio Editora, Rio de Janeiro.

MATTOS, Carlos de Meira, 1980: Uma Geopolítica Pan- Amazônica, Livraria José Olímpio Editora, Rio de Janeiro.

MAZZEI, Valdir, 1999: Amazônia Sul-Americana: Um Novo Espaço de Integração, dissertação de mestrado, Departamento de Geografia da Faculdade de Filosofia, Letras e Ciências Humanas da Universidade de São Paulo.

McKIBBEN, Bill, 2001: "El invernadero de Bush", in Revista Política Exterior, vol. XV, no. 83, sep-oct/01.

MELlo, Neli Aparecida de, 2002: Políticas Públicas Territoriais na Amazônia Brasileira: Conflitos entre conservação ambiental $e$ desenvolvimento - 1970-2000, tese de doutoramento, Departamento de Geografia da Faculdade de Filosofia, Letras e Ciências Humanas da Universidade de São Paulo/Université de Paris X Nanterre.

NYE Jr., Joseph S., 1997: Understanding International Conflicts - An Introduction to Theory and History, 2nd edition, Longman.

PIRAGES, Dennis, 1978: The New Context for International Relations. Global Ecopolitics, Duxbury Press, North Scituate, Massachusetts.

PORTER, Gareth, BROWN, Janet Welsh \& CHASEK, Pamela S., 2000: Global Environmental Politics, third edition, Westview Press, Boulder (Colorado) and Oxford (U.K.).

QUINTÃO, Geraldo, 28 de agosto de 2000: Defesa, Diplomacia e o Cenário Estratégico Brasileiro, palavras proferidas aos alunos do Instituto Rio Branco [constante no site na internet do Ministério das Relações Exteriores].

RATTNER, Henrique, 2002: "Meio ambiente e desenvolvimento sustentável: o mundo na encruzilhada da História", in Revista Política Externa, vol. 11, no. 2, set-out- nov/02.

SCHMITT, Carl, 1985: La dictadura, Alianza Editorial, Madrid [original de 1931]. 
SILVA, Golbery do Couto e, 1967: Geopolítica do Brasil, 2a. ed., Livraria José Olympio Editora, Rio de Janeiro.

SILVA-SÁNCHEZ, Solange S., 2000: Cidadania Ambiental: Novos Direitos no Brasil, Humanitas-FFLCH- USP/Annablume, São Paulo.

SWITZER, Jacqueline Vaughn \& BRYNER, Gary, 1998: Environmental Politics - Domestic \& Global Dimensions, 2nd ed., Bedford/St. Martin, Boston and New York [original de 1992].

TRAVASSOS, Mario, 1935: Projeção Continental do Brasil, Companhia Editora Nacional, São Paulo.

VILLA, Rafael A. Duarte, 1999: Da Crise do Realismo à Segurança Global Multidimensional, Annablume, São Paulo.

WEBER, Max, 1999: "A Política Como Vocação", in Ciência e Política duas vocações, Cultrix, São Paulo [conferência datada de 1918].

\section{BIBLIOGRAFIA CONSULTADA}

ANNAN, Kofi A., 1999: The Question of Intervention, United Nations, New York.

BAPTISTA, Luiz Olavo \& FONSECA, José Roberto Franco da (coords.), 1998: O Direito Internacional no Terceiro Milênio - Estudos em Homenagem ao Professor Vicente Marotta Rangel, LTr, São Paulo.

BARROS, Alberto Ribeiro de, 2001: A teoria da soberania de Jean Bodin, Unimarco, São Paulo.

BECKER, Bertha, 2000: "Reflexões sobre políticas de integração nacional e desenvolvimento regional", in Reflexões sobre políticas de integração nacional e de desenvolvimento regional, Ministério da Integração Nacional.

BOBBIO, Norberto, 1991: Thomas Hobbes, Campus, Rio de Janeiro [ensaios originalmente de 1948 a 1982].

BOBBIO, Norberto, 1995: O Positivismo Jurídico, Ícone, São Paulo.

BODIN, Jean, 1996: On Sovereignty - Four chapters from The Six Books of the Commonwealth, edited by Julian H. Franklin, Cambridge University Press [publicação de 1992].

CARVALHO, José Carlos, s.d.: "O Brasil e a Cúpula Mundial sobre Desenvolvimento Sustentável de Joannesburgo", mimeo [constante no site da internet do Comitê Brasileiro do Programa das Nações Unidas para o Meio Ambiente].

CAVAGNARI Filho, Geraldo Lesbat, 2000: "Subsídios para revisão da política de defesa nacional", mimeo [constante no site da UNICAMP]

CONCA, Ken \& DABELKO, Geoffrey (eds.), 2002: Environmental Peacemaking, Woodrow Wilson Center Press e John Hopkins U. P. Washington DC, Baltimore and London.

FLORES, Mário César, 1992: Bases para uma política militar, Editora da UNICAMP, Campinas. 
GOLDEMBERG, José, 2002: “Um plano de ação para Johannesburg”, in Revista Política Externa, vol. 11, no. 1, jun- jul-ago/02.

GOLDENBERG, Mirian (coord.), 1992: Ecologia, Ciência e Política, Editora Revan, Rio de Janeiro.

HAGE, José Alexandre A., 2002: "Direito do meio ambiente e política internacional: problemas sobre pesquisa e ocupações espaciais", in Revista Política Externa, vol. 11, no. 1, jun-jul- ago/02.

HIRST, Paul \& THOMPSON, Grahame, 1998: Globalização em questão, Vozes, Petrópolis [original de 1996].

HOBBES of Malmesbury, Thomas, 1966: English Works, 2nd reprinting, 11 volumes, Scientia Verlag Aalen, Germany [compilado e editado originalmente por Sir William Molesworth, Bart.; publicado originalmente em 1839].

HOBBES, Thomas, 1998: Do Cidadão, Martins Fontes, São Paulo [original de 1642].

HOFFMANN, Helga, 2002: "Tudo o que existe sob o sol e mais além: rumo à ECO 2002", in Revista Política Externa, vol. 11, no. 1, junjul-ago/02.

HURRELL, Andrew, \& KINGSBURY, Benedict (orgs.), 1992: The International Politics of Environment, Claredon Press, Oxford.

KENNEDY, Paul, 1993: Preparando para o século XXI, Campus, Rio de Janeiro.

KRITSCH, Raquel, 2002: Soberania: a construção de um conceito, Humanitas/Imprensa Oficial do Estado, São Paulo.

LEIS, Héctor R. (org.), 1991: Ecologia e Política Mundial, FASE/Vozes/PUC-Rio, Rio de Janeiro.

LOTTENBERG, Fernando Kasinski, 1997: A Construção do Direito de Ingerência na Paz do Pós Guerra Fria, tese de doutoramento, Departamento de Direito Internacional da Faculdade de Direito da Universidade de São Paulo.

MACEDO, Sérgio D. T., s.d.: Transamazônica - Integração-Redenção do Norte, Record, São Paulo.
MACEDO Jr., Ronaldo Porto, 1993: Carl Schmitt e a Fundamentação do Direito, dissertação de mestrado, Departamento de Filosofia da Faculdade de Filosofia, Letras e Ciências Humanas da Universidade de São Paulo, São Paulo.

MELLO, Leonel Itaussu Almeida, 1997: A Geopolítica do Brasil e a Bacia do Prata, Editora da Universidade do Amazonas, Manaus.

MIYAMOTO, Shiguenoli, 1992: A Questão Ambiental e as Relações Internacionais, Coleção Primeira Versão, no. 42, IFCH/UNICAMP.

PELLICER, Olga, 1995: "Nuevas Avenidas para la Acción de la ONU; el Debate sobre la Intervención en asuntos internos de los Estados”, in Revista Foro Internacional, vol. 35, vol. 4, oct.-dic./95.

RIBEIRO, Wagner Costa, s.d.: "Globalização e Meio- Ambiente: a Ordem Ambiental Internacional", mimeo.

SCHMITT, Carl, 1992: O Conceito do Político, Vozes, Petrópolis, [textos originalmente de 1929 e 1932].

STOPPINO, Mario, 1986: verbetes "Força" e "Poder", in Norberto BOBBIO, Nicola MATTEUCCI \& Gianfranco PASQUINO: Dicionário de Política, UnB, Brasília [original de 1983].

VIOLA, Eduardo, et alli., 1998: Meio Ambiente, Desenvolvimento e Cidadania, 2a. edição, Cortez Editora/Editora da UFSC, São Paulo/Florianópolis.

WEBER, Max, 1986: “Os três tipos puros de dominação legítima”, in Max Weber - Sociologia, Editora Ática, São Paulo [original de 1956].

WILHELMY, Manfred, "Evolución del sistema internacional", in Política internacional: enfoques y realidades, Colección Estudios Internacionales, Grupo Editor Latinoamericano, Buenos Aires, 1998. 